
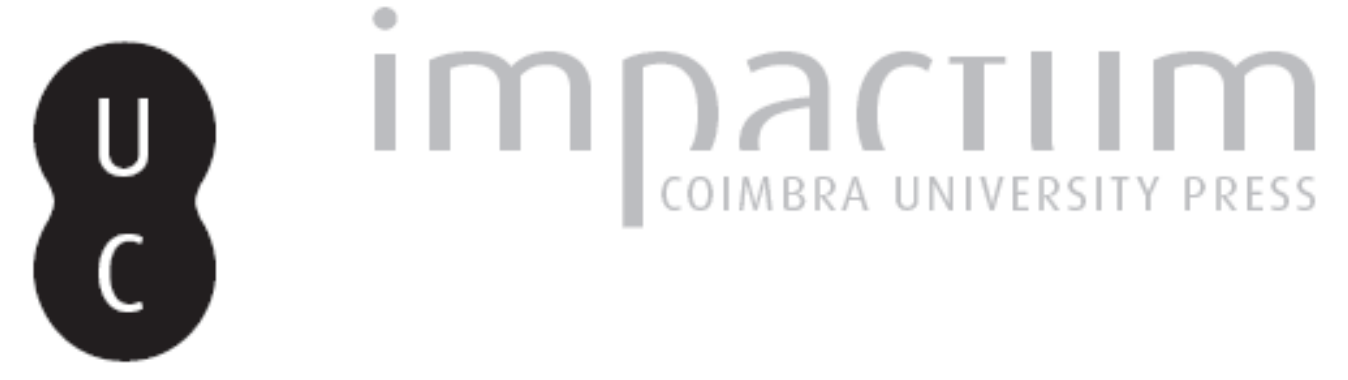

\title{
Riscos e danos ambientais na jurisprudência brasileira do STJ: um exame sob a perspectiva do Estado de Direito Ambiental
}

Autor(es): $\quad$ Belchior, Germana Parente Neiva; Leite, José Rubens Morato

Publicado por: CEDOUA

URL persistente:

URI:http://hdl.handle.net/10316.2/8835

DOI:

http://dx.doi.org/10.14195/2182-2387_22_3

Accessed : $\quad$ 26-Apr-2023 14:47:31

A navegação consulta e descarregamento dos títulos inseridos nas Bibliotecas Digitais UC Digitalis, UC Pombalina e UC Impactum, pressupõem a aceitação plena e sem reservas dos Termos e Condições de Uso destas Bibliotecas Digitais, disponíveis em https://digitalis.uc.pt/pt-pt/termos.

Conforme exposto nos referidos Termos e Condições de Uso, o descarregamento de títulos de acesso restrito requer uma licença válida de autorização devendo o utilizador aceder ao(s) documento(s) a partir de um endereço de IP da instituição detentora da supramencionada licença.

Ao utilizador é apenas permitido o descarregamento para uso pessoal, pelo que o emprego do(s) título(s) descarregado(s) para outro fim, designadamente comercial, carece de autorização do respetivo autor ou editor da obra.

Na medida em que todas as obras da UC Digitalis se encontram protegidas pelo Código do Direito de Autor e Direitos Conexos e demais legislação aplicável, toda a cópia, parcial ou total, deste documento, nos casos em que é legalmente admitida, deverá conter ou fazer-se acompanhar por este aviso.

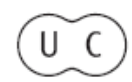





\title{
Riscos e danos ambientais na jurisprudência brasileira do ST): um exame sob a perspectiva do Estado de Direito Ambiental
}

\begin{abstract}
A sociedade de risco, oriunda da pós-modernidade, exige transformações no Estado e no Direito de forma a minimizar os impactos da crise ambiental e controlar as dimensões do risco. Diante disso, constata-se que a racionalidade jurídica clássica não é suficiente para lidar com a complexidade que permeia o dano ambiental, na medida em que referida discussão ultrapassa um olhar técnico e meramente dogmático. O objetivo geral desse artigo é investigar como a jurisprudência brasileira do Superior Tribunal de Justiça vem tratando da juridicidade dos riscos e dos danos ambientais à luz do Estado de Direito Ambiental. Constata-se que a Corte Especial brasileira vem se mostrando sensível à complexidade ambiental de forma a materializar e amadurecer as peculiaridades da responsabilidade civil ambiental.
\end{abstract}

\section{Introdução}

A sociedade de risco, oriunda da pós-modernidade, demanda transformações no Estado e no Direito de forma a minimizar os impactos da crise ambiental e controlar as dimensões do risco. Se lidar com o risco certo e em potencial, utilizando a expressão de Beck, já era difícil no paradigma anterior, imagina gerir riscos imprevisíveis, em abstrato, em virtude das incertezas científicas.

A racionalidade jurídica clássica, pautada na segurança e em conceitos engessados, não é suficiente para lidar com a complexidade que permeia o dano ambiental, na medida em que referida discussão ultrapassa um olhar técnico e meramente dogmático. Por outro lado, é mister compreender a crise ambiental por meio de uma visão transdisciplinar e de um enfoque mais sociológico do risco, pois o Direito também se produz da realidade e não apenas das normas formalizadas, próprio do movimento dialético. Nessa linha, urge a criação de uma nova gestão preventiva, a partir da utilização de instrumentos preventivos e precaucionais, para tratar de toda a complexidade ambiental que paira pela sociedade hodierna, influenciando diretamente a responsabilidade civil por dano ambiental.

O objetivo geral desse artigo é, portanto, investigar como a jurisprudência brasileira do Superior Tribunal de Justiça vem tratando da juridicidade dos riscos e dos danos ambientais à luz do Estado de Direito Ambiental. A metodologia utilizada na pesquisa é teórica, bibliográfica, descritiva, exploratória, jurisprudencial e dialética com predominância indutiva, 
pois se busca discutir os elementos da responsabilidade civil ambiental a partir da teoria da sociedade de risco por meio da utilização de instrumentos hermenêuticos próprios do Estado de Direito Ambiental.

Em um primeiro momento do estudo, analisa-se a complexidade da responsabilidade civil por dano ambiental sob o viés da sociedade de risco. Em seguida, discute-se a necessidade de um Estado de Direito Ambiental e a emergência de uma Hermenêutica Jurídica particular para lidar com as demandas ecológicas. Aborda-se, ainda, a responsabilidade civil ambiental no ordenamento jurídico brasileiro para averiguar as novas funções que referido instituto assume em face de uma gestão preventiva e precaucional do risco. Por fim, passa-se a discutir cinco decisões do Superior Tribunal de Justiça sobre a problemática dos riscos e danos ambientais de forma a verificar se a Corte Especial brasileira vem ou não avançando acerca do tema.

\section{Aspectos em torno da sociedade de risco e da complexidade da responsabilidade civil por dano ambiental}

A revolução industrial do século XVIII foi o embrião do que se chama hoje de sociedade de risco ${ }^{1}$, potencializada pelo desenvolvimento tecno-científico e caracterizada pelo incremento na incerteza quanto às conseqüências das atividades e tecnologias empregadas no processo econômico. ${ }^{2}$

Notadamente, a sociedade pós-moderna produz riscos que podem ser controlados e outros que escapam ou neutralizam os mecanismos de controle típicos da sociedade industrial. A sociedade de risco revela-se, portanto, como um modelo teórico que marca a falência da modernidade, emergindo de um período pós-moderno, na medida em que as ameaças produzidas ao longo da sociedade industrial começam a tomar forma. Os pilares da concepção moderna de civilização já não conseguem mais explicar os desenvolvimentos da ciência e da sociedade. Trata-se de uma crise de paradigma, uma crise própria da modernidade. Referida crise torna praticamente inviável, pelo menos nos moldes clássicos, qualquer tentativa do homem pós-moderno no sentido de calcular os riscos e os desafios a que se submete o meio ambiente no século XXI.

Sobre o tema, destaca Milaré que "os avanços proporcionados pela ciência e pela técnica não significam necessariamente uma elevação do progresso e do bem-estar, como se pensou a partir da Idade Moderna, na linha de uma espécie de 'otimismo técnico'."' Explica, ainda, o autor que "a racionalidade técnica deixa de ser encarada como um instrumento neutro para a promoção de objetivos da humanidade, sendo indiscutivel a sua potencialidade para se

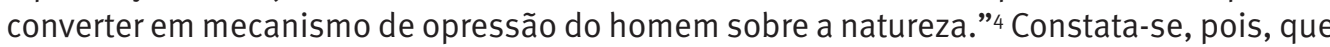
aquilo que um dia foi motivo de esperança é hoje sinônimo de inquietação. A crise ambiental é percebida no descuido com a natureza, como mais um dos fracassos da modernidade.

Caracteriza-se, ainda, a pós-modernidade pela liquidez dos conceitos. Diz-se líquido aquilo que não é sólido, isto é, o que não se enquadra em formas rígidas. Ao contrário,

\footnotetext{
${ }^{1}$ A teoria da sociedade de risco foi inicialmente fundamentada pelo sociólogo alemão Ulrick Beck, com a publicação da obra "La sociedad del riesgo", em meados da década de 80. Segundo Beck, a sociedade de risco "designa uma fase no desenvolvimento da sociedade moderna, em que os riscos sociais, políticos, econômicos e individuais tendem cada vez mais a escapar das instituições para o controle e a proteção da sociedade industrial”. BECK, Ulrick. La sociedade del riesgo. Tradução de Jorge Navarro. Barcelona: Paidós, 1998, p. 24.

${ }^{2}$ ROCHA, Leonel Severo. Uma nova forma para a observação do direito globalizado: policontextualidade jurídica e Estado Ambiental. In: Grandes Temas de Direito Administrativo: homenagem ao Professor Paulo Henrique Blasi. CARLIN, Volvei Ivo (org.). Campinas: Millennium, 2009, p.527.

${ }^{3}$ MILARÉ, Édis. Amplitude, limites e prospectivas do Direito do Ambiente. In: Sustentabilidade e temas fundamentais de direito ambiental. MARQUES, José Roberto (org.). Campinas: Millennium, 2009, p. 140.

${ }^{4}$ Ibid., p. 140.
} 
trata-se de conceitos maleáveis, flexíveis, fluidos. Essa nova realidade reflete diretamente na vida do homem que sofre diante da crise de valores, da falta de referência, relatado por Bauman. ${ }^{5}$ Referida liquidez se coaduna com o risco ambiental.

Nessa linha, Beck aponta a existência de duas modalidades de risco: o concreto ou potencial, que é visível e previsível pelo conhecimento humano; e o abstrato, que tem como característica a invisibilidade e a imprevisibilidade pela racionalidade humana. No âmbito do Direito Ambiental, tem-se que o risco concreto ou potencial é controlado pelo princípio da prevenção, enquanto o abstrato encontra-se amparado no princípio da precaução, ao investigar a probabilidade de o risco existir por meio da verossimilhança e de evidências, mesmo não detendo o ser humano a capacidade perfeita de compreender este fenômeno. ${ }^{6}$

Dessa forma, é certo que toda essa difusão subjetiva, temporal e espacial das situações de risco, perigo e dano, conduzem a pensar o meio ambiente de forma diferente, superando o modelo jurídico tradicional. É inconteste que o risco, atualmente, é um dos maiores problemas e desafios a serem enfrentados, quando se objetiva uma efetiva proteção jurídica do meio ambiente, especialmente no que concerne à responsabilização e à reparação do dano ambiental.

Sob a mesma ideia de Beck, aponta Giddens que o risco é expressão de sociedades que se organizam sob a ênfase da inovação, da mudança e da ousadia. Questiona-se, por conseguinte, a própria prudência e cautela da ciência em lidar com as inovações tecnológicas e ambientais que, mesmo trazendo benefícios, estão causando riscos sociais não mensuráveis.?

Para agravar ainda mais o clima de incertezas a que se está imerso, o desenvolvimento econômico abafa as conseqüências negativas do seu progresso, isto é, há uma invisibilidade dos riscos ecológicos, decorrente do fato de que o Estado e os setores privados interessados utilizam meios e instrumentos para ocultar as origens e os efeitos do risco ecológico, com o objetivo de diminuir suas conseqüências, ou melhor, com o fim de transmitir para a sociedade uma falsa ideia de que o risco ecológico está controlado.

É o que Beck apontou como irresponsabilidade organizada. ${ }^{8}$ Para o sociólogo alemão, apesar da consciência da existência de riscos, estes são ocultados pelo Poder Público e pelo setor privado. Assim, a irresponsabilidade organizada acaba transformando o Estado em faz-de-conta, em Estado fantoche, que só dá publicidade aos fatos científicos de acordo com seus interesses. ${ }^{9}$

É de se notar que a sociedade hodierna está pautada em uma irresponsabilidade organizada, haja vista que as instituições públicas e civis parecem ainda não terem se despertado para a necessidade de uma gestão compartilhada do risco. Aliás, caso tenham se atentado, é preferível o silêncio, contribuindo para um anonimato geral. No entanto, na medida em que a sociedade percebe uma incongruência do discurso público com as conseqüências da crise ambiental e dos riscos a ela inerentes, perde-se o referencial sólido do próprio Poder Público, incorporando-se à liquidez sugerida por Bauman.

Não se pode viver, entretanto, tão vulnerável aos riscos e às incertezas, de forma total, sob pena de se encontrar em um verdadeiro caos ou retroceder ao estado de natureza hobbesiano. Nesse sentido, o Direito, como ciência, precisa abrir espaços para discussões em torno de novas formas de sociabilidade, por meio da criação de instrumentos jurídicos que

\footnotetext{
5 BAUMAN, Zygmunt. O mal-estar da pós-modernidade. Tradução de Mauro Gama, Claudia Martinelli Gama. Rio de Janeiro: Jorge Zahar, 1998, p. 155.

${ }^{6}$ Os princípios da precaução e da prevenção serão discutidos mais adiante.

7 GIDDENS, Anthony. Mundo em descontrole: o que a globalização está fazendo de nós. 2. ed. Tradução de Maria Luiza X. de A. Borges. Rio de Janeiro: Record, 2002, p. 44-45.

${ }^{8}$ BECK, Ulrich. Ecological Politics in an Age of Risk. Londres: Polity Publications, 1995, p. 61.

${ }^{9}$ LEITE, José Rubens Morato; BELCHIOR, Germana Parente Neiva. Estado de Direito Ambiental: uma análise da recente jurisprudência do STJ sob o enfoque da hermenêutica jurídica. Revista de Direito Ambiental, a. 14, v. 56, out./nov., p. 55-92, São Paulo: Revista dos Tribunais, 2009, p. 60.
}

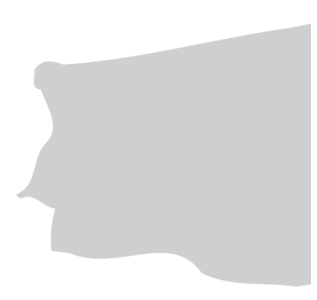


busquem trazer à baila medidas de gerenciamento preventivo do risco, baseado nos princípios da prevenção, da precaução, da responsabilização e da solidariedade.

Nesse contexto, merece discussão a distribuição dos malefícios que acompanham a produção de bens, principalmente quando se trata de impactos negativos ao meio ambiente, uma vez que os mesmos atingem não apenas a vida humana da atual geração, mas a de todos os seres vivos em caráter intergeracional. Encontra-se diante de riscos inseguráveis, originados de processos de decisão desenvolvidos em espaços institucionais de acentuado déficit democrático, cujos efeitos atingem gerações em uma escala espacial e temporal de difícil determinação pela ciência. ${ }^{10}$

0 atual tipo de desenvolvimento é autolimitado, não conseguindo gerir as conseqüências do modelo de produção por ele criado. É mister, pois, reavaliar os padrões de responsabilidade, segurança, controle e conseqüências do dano à luz das limitações científicas do risco. Oportuno destacar a observação de Ayala:

[...] a possibilidade de um futuro não é promessa, mas compromisso, que só pode ser realizado mediante uma tríade de condições estruturadas em torno da participação da informação e da repartição de responsabilidades (solidariedade). 0 possível deixa, desta forma, de ser socialmente reproduzido como expressão que identifica condições de imobilismo ou de impotência perante um futuro inacessível, desconhecido, e incompreensivel, para assumir a qualidade de objetivo de compromisso jurídico tendente à concretização, tarefa que dependem de severos compromissos de solidariedade. ${ }^{11}$

Percebe-se, claramente, que há necessidade de o Estado melhor se organizar e facilitar o acesso aos canais de participação, gestão e decisão dos problemas e dos impactos oriundos da irresponsabilidade política no controle de processos econômicos de exploração inconseqüente dos recursos naturais em escala planetária.

Ao transpor a teoria do risco para a responsabilidade civil, cujos elementos foram construídos sob as bases do racionalismo e das certezas científicas, é necessária a rediscussão do referido instituto, a fim de adequá-lo às exigências não apenas do risco concreto ou em potencial, mas principalmente do abstrato, que se revela como imprevisível pelo conhecimento humano. Em outras palavras, ao analisar o instituto do dano ambiental, não basta simplesmente importar os elementos da responsabilidade civil para o Direito Ambiental, sob pena de o sistema jurídico exercer uma função figurativa e simbólica, distante de uma efetiva proteção do meio ambiente. ${ }^{12}$

Isso decorre do fato de que a responsabilização civil, em sua forma tradicional, tem como meta um post fato, na medida em que lida com o dano já ocorrido. É de se notar, portanto, que o sistema da responsabilidade deve se adaptar para reexaminar o nexo de causalidade, a tolerabilidade, a aceitabilidade, a exclusão de responsabilidade e, ainda, a complexidade da lesividade ambiental. Outro ponto que merece atenção são os instrumentos de reparação do dano e, diante da sua impossibilidade, buscar a compensação ecológica. Como se vê, trata-se de elementos imprescindiveis aos novos contornos do modelo de responsabilidade por dano ambiental.

É emergencial, por conseguinte, a construção de um Estado de Direito Ambiental que venha a se adequar à crise ecológica e à sociedade de risco a partir da fundamentação teórica de princípios fundantes e estruturantes, contornos e metas para tentar minimizar os efeitos dos impactos negativos no meio ambiente.

${ }^{10}$ LEITE, José Rubens Morato; AYALA, Patrick de Araújo. Direito ambiental na sociedade de risco. Rio de Janeiro: Forense, 2004 .

${ }^{11}$ AYALA, Patryck de Araújo. A proteção jurídica das futuras gerações na sociedade do risco global: direito ao futuro na ordem constitucional brasileira. IN: LEITE, Jose Rubens Morato e FERREIRA, Heline Sivini (ORG). Estado de Direito Ambiental: Aspectos Constitucionais e Diagnósticos. Rio de Janeiro: Forense Universitária, 2004.

${ }_{12}$ PAUL, Wolf. A irresponsabilidade organizada? In: OLIVEIRA JUNIOR, José Alcebíades (org.). O novo em Direito e política. Porto Alegre: Livraria do Advogado, 1997, p. 178-188. 


\section{Emergência de um Estado de Direito Ambiental e a necessidade de um novo viés hermenêutico}

A sociedade de risco, oriunda da pós-modernidade, demanda transformações no Estado e no Direito de forma a minimizar os impactos da crise ambiental e controlar as dimensões do risco. Estado e Direito caminham juntos, um complementando o outro, com o objetivo de pacificação social. O Direito é, pois, o discurso que legitima o papel do Estado. Parece que no atual contexto do risco, vinculado diretamente à problemática ambiental, urge modificações teóricas e funcionais no âmbito do Direito e do Estado. Se lidar com o risco certo e em potencial, utilizando a expressão de Beck, já era difícil no paradigma anterior, imagina gerir riscos imprevisíveis, em abstrato, em virtude das incertezas científicas. Nessa linha, é preciso criar uma nova gestão preventiva, por meio da utilização instrumentos preventivos e precaucionais, para lidar com toda a complexidade ambiental que paira pela sociedade hodierna.

A partir do momento que se constata que o meio ambiente sadio é condição para a vida em geral e que a sociedade de risco torna cada vez mais complexa a tarefa de lidar com o dano ambiental, é emergencial um Estado preocupado com a questão ecológica. De uma forma objetiva, o Estado de Direito Ambiental pode ser compreendido como produto de novas reivindicações fundamentais do ser humano e particularizado pela ênfase que confere à proteção do meio ambiente. Observa Capella que a construção do Estado de Direito Ambiental pressupõe a aplicação do princípio da solidariedade econômica e social com o propósito de se alcançar um modelo de desenvolvimento duradouro, orientado para a busca da igualdade substancial entre os cidadãos mediante o controle jurídico do uso racional do patrimônio natural. ${ }^{13}$

Não obstante o Estado de Direito Ambiental ser, em um primeiro momento, uma abstração teórica, o tratamento que a lei fundamental de um determinado país confere ao meio ambiente pode aproximar ou afastar o seu governo dos avanços propostos pelo Estado de Direito Ambiental, servindo de meta e parâmetro para este.

Diante de tal consideração, é oportuno assinalar que a Constituição Federal de 1988 foi o primeiro diploma constitucional do Brasil a versar deliberadamente sobre o meio ambiente, dispensando à matéria um tratamento amplo e diferenciado. A partir de um capítulo especificamente dedicado ao tema, o constituinte definiu o que viria a se tornar o núcleo normativo do direito ambiental brasileiro.

A proteção constitucional do meio ambiente, entretanto, é mais extensa, abrangendo uma série de outros dispositivos que, direta ou indiretamente, relacionam-se a valores ambientais de forma holística e sistêmica. Nessa linha, ilustra Benjamin que o capítulo que versa sobre o meio ambiente nada mais é do que o ápice ou a face mais visível de um regime constitucional que se dedica de forma difusa à gestão dos recursos ambientais. ${ }^{14}$

Há princípios estruturantes do Estado de Direito Ambiental como o princípio da precaução, o princípio da prevenção, o princípio da responsabilização, o princípio do poluidor-pagador, o princípio da participação, o princípio da cidadania, princípio da democracia, princípio da informação, princípio da proibição do retrocesso ecológico e princípio do mínimo existencial ecológico. No entanto, ao analisar todos esses princípios, percebe-se que a solidariedade acaba estando inserida seja de forma transversal ou direta em todos os demais. Por conta disso, é que o princípio da solidariedade é o fundamento teórico-jurídico do Estado de Direito Ambiental, ou seja, um dos princípios fundantes do novo paradigma estatal, o que não exclui, por conseguinte, os demais.

\footnotetext{
${ }^{13}$ CAPELLA, Vicente Bellver. Ecologia: de las razones a los derechos. Granada: Ecorama, 1994.

${ }^{14}$ BENJAMIN, Antônio Herman. Constitucionalização do ambiente e ecologização da Constituição brasileira. In: LEITE, José Rubens Morato; CANOTILHO, José Joaquim Gomes (orgs.). Direito constitucional ambiental brasileiro. 2. ed. São Paulo: Saraiva, 2008.
} 
A crise ambiental não ocorre de formada isolada, o que leva a constatar que a dignidade da pessoa humana não pode ser vista tão-somente no indivíduo, mas também em uma dimensão coletiva em sentido geral. Por conseguinte, traz à baila direitos que perpassam a esfera privada e se subordinam a interesses da maioria em prol do bem-estar social, em virtude da titularidade ser indefinida ou indeterminável. Assim, o princípio da solidariedade surge como instrumento que obriga que referidos direitos devam ser garantidos às gerações futuras, assumindo a dimensão intergeracional.

Para tanto, resta verificar se a Carta Magna brasileira tem condição de recepcionar o novo modelo de Estado, vez que "a construção do Estado de Direito Ambiental passa, necessariamente, pelas disposições constitucionais, pois são elas que exprimem os valores e os postulados básicos da comunidade nas sociedades de estrutura complexa, nas quais a legalidade representada racionalidade e objetividade". ${ }^{15}$

A Constituição Federal de 1988 trata do princípio da solidariedade como objetivo da República em seu artigo $3^{\circ}$, I, ao prever a "construção de uma sociedade livre, justa e solidária." No inciso IV do mesmo artigo, visualiza-se outro objetivo que comprova a preocupação do constituinte originário com a solidariedade, ao estabelecer a "erradicação da pobreza e da marginalização social e a redução das desigualdades sociais e regionais". Como se vê, os dispositivos estabelecem um novo marco normativo-constitucional, ao consolidar a solidariedade como princípio da Lei Maior. ${ }^{16}$

Ainda no Texto Constitucional, o art. 225, núcleo do ambientalismo constitucional, cuida da solidariedade ao impor ao Poder Público e à coletividade o dever de proteger o meio ambiente para as presentes e futuras gerações. Não há duvida de que o dever fundamental está diretamente relacionado ao princípio da solidariedade por dividir os encargos e responsabilidades na equidade geracional.

Outrossim, o citado princípio encontra guarida em tratados internacionais de direitos humanos de matéria ambiental ratificados pelo Estado brasileiro, em virtude da cláusula de abertura do $\S 2^{\circ}$, do art. $5^{\circ}$, da Constituição Federal. ${ }^{17}$

O princípio da solidariedade aparece com um dos grandes desafios aos juristas por conta da teoria do risco, na medida em que demanda relacionamento entre as diversas gerações, o que torna a temática complexa, pois não se sabe o que estar por vir. Ilustra Benjamin que só cabe fazer algumas conjecturas sobre "a) quem habitará o planeta num futuro muito além dos dias de hoje; b) as conseqüências remotas que nossas ações atuais provocarão nesses habitantes incertos; e, c) os tipos de preferência adotados por tais gerações". ${ }^{18}$

De antemão, já se afirma que não se trata de uma ruptura total com o Estado Democrático de Direito, modelo adotado pelo constituinte originário brasileiro de 1988 , nos termos do art. ${ }_{1}$. . Trata-se do acréscimo de novo princípio fundante e valor-base que, ao se vincularem com os já existentes na velha ordem, de forma equilibrada e holística, objetivam uma proteção mais efetiva da tutela ambiental. Assim, o princípio da solidariedade atuará de forma conjunta

${ }^{15}$ LEITE, José Rubens Morato; FERREIRA, Maria Leonor Paes Cavalcanti Ferreira. As novas funções do Direito Administrativo em face do Estado de Direito Ambiental. In: Grandes Temas de Direito Administrativo: homenagem ao Professor Paulo Henrique Blasi. CARLIN, Volnei Ivo (org.). Campinas: Millenium, 2009, p. 439.

${ }^{16}$ Interessante, ainda, mencionar que o princípio da solidariedade também está previsto no preâmbulo da Constituição Federal de 1988 ao asseverar que os direitos sociais e individuais, a liberdade, a segurança, o bem-estar, o desenvolvimento, a igualdade e a justiça como valores supremos de uma sociedade fraterna. Embora o preâmbulo careça de juridicidade, trata-se de uma carta de intenções do constituinte que não deixa de ser uma norma moral que manifesta os ideais e valores da sociedade.

${ }_{17}$ "Art. $5^{\circ}$. [...] $\S 2^{0}$ - Os direitos e garantias expressos nesta Constituição não excluem outros decorrentes do regime e dos princípios por ela adotados, ou dos tratados internacionais em que a República Federativa do Brasil seja parte." ${ }^{18}$ BENJAMIN, Antonio Herman. A Natureza no Direito Brasileiro: coisa, sujeito ou nada disso. In: Grandes Temas de Direito Administrativo: homenagem ao Professor Paulo Henrique Blasi. CARLIN, Volnei Ivo (org.). Campinas, Millenium, 2009, p. 59. 
com o princípio da legitimidade ("Estado Democrático") e com o princípio da juridicidade ("Estado de Direito"), além de outros que incorporam valores eleitos pelo constituinte.

É importante destacar que não se trata de uma questão formal, um registro de surgimento de um novo Estado. De fato, não é tão importante para a Ciência Jurídica os nomes atribuídos aos institutos, mas sim a natureza jurídica dos mesmos. É claro que um nome que é dado a um Estado não transformará a realidade da noite para o dia. Decerto que não. 0 que se pretende, na defesa de um Estado de Direito Ambiental, é o fortalecimento de um novo olhar, de uma consciência ecológica, de diferentes funções, instrumentos, metas e tarefas que possam (e devam) ser utilizados pelo Poder Público e pela coletividade, de forma integrada, preventiva, precaucional e solidária.

Como se vê, não é um discurso romântico ou utópico, mas um paradigma possível de ser efetivado. Não se nega, entretanto, a dificuldade de efetivá-lo, com elementos integrantes sólidos e adequados, a fim de que sejam implementados pelos Estados hodiernos na concretização do novo princípio-base da solidariedade e do valor da sustentabilidade.

No entanto, de nada adianta toda uma construção teórica em torno do Estado de Direito Ambiental, se não existirem mecanismos concretos de efetivação. Ao adotar o paradigma ecológico, é necessário um novo modo de ver a ordem jurídica, com uma pré-compreensão diferenciada do intérprete, na medida em que a hermenêutica filosófica comprova que o sentido a ser captado da norma jurídica é inesgotável. As normas precisam ser interpretadas de forma a concretizar o Estado de Direito Ambiental. Por mais que a Constituição permaneça em muitos pontos inalterada, e até mesmo as normas infraconstitucionais, o intérprete deve perceber o movimento dialético do Direito, formado poor raciocínios jurídicos não apenas dedutivos, mas também indutivos, o que justifica a emergência de uma Hermenêutica Jurídica Ambiental. ${ }^{19}$

A particularidade de uma Hermenêutica Ambiental se fortalece, ainda, pelo fato de a ordem jurídica ambiental ser dotada de conceitos vagos, confusos, amplos e indeterminados, além da intensa discricionariedade administrativa que é concedida ao Executivo. 0 próprio conceito de bem ambiental é juridicamente indeterminado, haja vista que suas condições, fatores e elementos estão em constante transformação. É um conceito emoldural que será preenchido pelo intérprete no caso concreto, de acordo com os conhecimentos científicos no momento de sua aplicação.

Destaca-se, ademais, que diante do caráter principiológico dos direitos fundamentais, é inevitável a constante colisão entre os mesmos, como ocorre entre o direito ao meio ambiente com o direito à propriedade, o direito à liberdade, o direito à iniciativa privada, o direito ao desenvolvimento, o direito ao pleno emprego, etc., levando à necessidade de técnicas interpretativas adequadas.

O neoconstitucionalismo demanda construção teórica que faça a devida adaptação dos institutos jurídicos aos padrões firmados pela Constituição ao fixar novos canônes de interpretação para as normas infraconstitucionais. Assim, urge um novo viés hermenêutico da ordem jurídica, tendo como novel valor a sustentabilidade, invadindo a esfera pública e privada por conta da Ecologização.

Nessa linha, a Hermenêutica Jurídica Ambiental é proposta por meio de princípios de interpretação que objetivam a busca de soluções justas e constitucionalmente adequadas para a interpretação de normas ambientais, influenciados por uma nova pré-compreensão ambiental.

Utilizam-se, para tanto, os princípios fundantes (princípio da legitimidade, princípio da juridicidade e princípio da solidariedade) e os princípios estruturantes (princípio da precaução, princípio da prevenção, princípios da responsabilização e do poluidor-pagador,

${ }^{19}$ BELCHIOR, Germana Parente Neiva. Hermenêutica e Meio Ambiente: uma proposta de Hermenêutica Ambiental para a efetivação do Estado de Direito Ambiental. 2009. 219 f. Dissertação (Mestrado em Direito Constitucional). Universidade Federal do Ceará, Fortaleza, 2009. 
princípios da democracia, da cidadania, da informação, da educação e da participação ambiental, princípio da proibição do retrocesso ecológico e princípio do mínimo existencial ecológico) do Estado de Direito Ambiental. ${ }^{20}$

É de se destacar, ainda, os princípios de interpretação constitucional, o princípio da razoabilidade, o princípio da ponderação e o princípio da proporcionalidade, os dois últimos próprios para lidar com a colisão entre direitos fundamentais. ${ }^{21}$ Todos os princípios acabam estando interligados, um dando suporte ao outro para fundamentar as tomadas de decisões do intérprete.A razoabilidade, a ponderação, a proporcionalidade e a precaução são o início e o fim da Hermenêutica Jurídica Ambiental, na medida em que o princípio da precaução tem natureza material e instrumental, manifestando-se, ainda, em in dubio pro ambiente. ${ }^{22}$ É um ás na manga do intérprete ecológico, pois na medida em que este se vê impossibilitado de usar outros instrumentos hermenêuticos, utilizará o princípio in dubio pro ambiente como forma de garantir o mínimo existencial ecológico, especialmente na colisão do direito ao meio ambiente com outros direitos fundamentais. Referida técnica "a favor da natureza" não deve ser utilizada de forma radical, como lembra Canotilho, pois a dimensão ambiental deve servista de forma equilibrada com as outras existenciais do ser humano, como propaga um antropocentrismo alargado.

Referidos métodos podem ser aplicados por todos os que lidam com o Direito Ambiental: pelo legislador ao elaborar as normas infraconstitucionais, em obediência à Constituição; pelo Executivo no momento da elaboração e da execução de políticas públicas, especialmente no caso de licenciamento ambiental em virtude da discricionariedade administrativa; e pelos procuradores que atuam na área ambiental. Por fim, a hermenêutica esverdeada é indicada aos magistrados que lidam cada vez mais com demandas ambientais, considerando, ainda, a tendência das varas especializadas no Judiciário brasileiro.

Por outro lado, não se pode ficar tão bitolado nos textos legais, como sugeria o positivismo jurídico, nem tampouco desconsiderá-lo como defende algumas vertentes jusnaturalistas e do direito livre. $O$ intérprete constitucional ambiental deve analisar a evolução social, própria da dialética do Direito, preenchendo as molduras deônticas dispostas na Constituição de acordo com o contexto social, realidade esta traduzida em uma sociedade de risco.

De todo modo, já fica claro que os princípios não têm como oferecer respostas únicas e exclusivas, haja vista que, como visto na hermenêutica filosófica, o sentido a ser captado da norma é inesgotável. Mesmo que o jurista utilize todos os princípios interpretativos, ainda assim haverá margem para subjetividade e arbitrariedade. Apesar de todas as dificuldades inerentes a questões existenciais e complexas do fenômeno hermenêutico, o intérprete deve fundamentar suas decisões e suas escolhas com base em argumentos que possam ser racionalmente justificados nos ditames da nova ordem constitucional ecológica, principalmente quando o pós-positivismo aponta que os princípios não precisam estar expressos para ter validade normativa.

\section{Fundamentação da responsabilidade civil por dano ambiental no ordenamento jurídico brasileiro}

A responsabilidade civil pode ser definida como a obrigação de indenizar o dano causado a outrem. De acordo com a teoria clássica, a responsabilidade civil compõe-se dos seguintes

\footnotetext{
${ }^{20}$ FENSTERSEIFER, Tiago. Direitos Fundamentais e Proteção do Ambiente. A Dimensão Ecológica da Dignidade Humana no Marco Jurídico-Constitucional do Estado Sociambiental de Direito. Porto Alegre. Livraria do Advogado,2008. ${ }^{21}$ HESSE, Konrad. A força normativa da Constituição. Tradução de Gilmar Ferreira Mendes. Porto Alegre: Sergio Antonio Fabris Editor, 2001.

${ }^{22}$ CANOTILHO, José Joaquim Gomes. Protecção do ambiente e direito de propriedade: crítica de jurisprudência ambiental. Coimbra: Coimbra, 1995, p. 83.
} 
elementos: o dano, pois sem ele não há objeto a ser reparado; a ação culposa ("lato sensu") do autor, que poderia ter evitado o resultado; e o nexo causal, que é o liame existente entre a conduta do agente e a consequência danosa, o que gera a obrigação de indenizar. Segundo a lição de Gonçalves: "responsabilidade civil é, assim, um dever jurídico sucessivo que surge para recompor o dano decorrente da violação de um dever jurídico originário." ${ }^{23}$

A constatação de que o meio ambiente não pode ser submetido ao uso indiscriminado se verifica na Constituição Federal, em seu art. 225, §3으, que assevera: "As condutas e atividades consideradas lesivas ao meio ambiente sujeitarão os infratores, pessoas físicas ou jurídicas, a sanções penais e administrativas, independentemente da obrigação de reparar os danos causados".

Extrai-se do art. $225, \S 3^{\circ}$, da Lei Maior ${ }^{24}$, que o ordenamento brasileiro adotou o caráter tríplice da responsabilidade ambiental, ao impor sanções civis, penais e administrativas. $\mathrm{Na}$ legislação infraconstitucional, é importante mencionar o art. 4ํㅡ, VII, da Lei n. 6.938/81, ao dispor que a Política Nacional do Meio Ambiente tem como um de seus objetivos "a imposição, ao poluidor e ao predador, da obrigação de recuperar e/ou indenizar os danos causados, e ao usuário, da contribuição pela utilização de recursos ambientais com fins econômicos".

Assim, vislumbra-se que a onerosidade pela poluição dos recursos ambientais constitui um instrumento de política pública para aconselhar o poluidor a uma racionalização na utilização dos subsídios naturais, com o objetivo de manter um equilíbrio entre as disponibilidades e as demandas, bem como o meio ambiente saudável e protegido.

Notadamente, o agente responsável pela provocação do dano ambiental tem o dever de reparar o meio ambiente. Contudo, a finalidade da reparação no Direito Ambiental é restabelecer o meio lesado ao status quo ante, ou seja, é a reconstituição do bem ambiental degradado. A reparação em pecúnia no instituto da responsabilidade ambiental só deve ser realizada quando se revelar inatingível a reparação específica.

A ordem jurídica ambiental brasileira adota a teoria da responsabilidade objetiva, haja vista que, ao constatar o nexo de causalidade entre o dano e a ação do agente, este será responsabilizado independentemente de culpa, conforme previsto no $\S 3^{\circ}$, art. 225, da Constituição Federal de 1988, em concomitância com o §1ํㅡ, art. 14, da Lei no 6.938/81. Trata-se, sem dúvida, de um avanço normativo, vez que a não necessidade de comprovação de culpa do agente degradador, por conta do risco da atividade exercida, facilita, pelo menos em tese, a responsabilização.

Há muitas dificuldades, entretanto, que precisam ser vencidas, a fim de que o princípio da responsabilização seja efetivo, como "legitimação, avaliação do dano, autorização administrativa e dano ambiental, nexo causal”25, dentre outros. Caberá ao intérprete, em especial o Judiciário, o importante papel de resolução de questões complexas em virtude do dano ambiental, com vistas a efetivar o Estado de Direito Ambiental.

A responsabilidade objetiva desempenha tarefa primordial na reparação de prejuízo ao meio ambiente, pois, além de dar uma proteção mais abrangente a ele, bem de uso comum do povo e indispensável à sadia qualidade de vida, dispensa a prova da culpa do poluidor, difícil de ser conseguida devido às características do dano ambiental.

\footnotetext{
${ }^{23}$ GONÇALVES, Carlos Roberto. Comentários ao Código Civil. São Paulo: Saraiva, 2003, v. 11, p. 7.

24 “Art. 225. [...] §3ํ․ As condutas e atividades consideradas lesivas ao meio ambiente sujeitarão os infratores, pessoas físicas ou jurídicas, a sanções penais e administrativas, independentemente da obrigação de reparar os danos causados".

${ }^{25}$ LEITE, José Rubens Morato. Dano ambiental: do individual ao coletivo extrapatrimonial. 2. ed. São Paulo: Revista dos Tribunais, 2003 , p. 64.
} 


\section{Novas funções da responsabilidade civil por dano ambiental em face da sociedade de risco}

Resta claro, até o momento desse estudo, que a responsabilidade civil ambiental possui uma complexa juridicidade em relação ao sistema tradicional do Direito Civil. Nessa linha, importa sintetizar algumas diferenças essenciais entre o dano ambiental e o dano tradicional para, então, perceber as novas funções que o instituto exerce (e deve exercer) em relação à proteção do meio ambiente.

Enquanto o dano tradicional está vinculado à pessoa e aos seus bens considerados de forma individual; o ambiental é difuso, de titularidade indefinida ou indeterminável, haja vista que protege um bem de interesse difuso e de uso comum do povo. Pode, ainda, gerar um dano ambiental reflexo quando a lesão também atinge indivíduos.

Como se discutiu anteriormente, a lesão tradicional está amparada na certeza, na segurança, uma vez que não há dúvida do dano ocorrido, sendo o mesmo definido, além de possuir quase sempre uma visibilidade. 0 dano ambiental, ao revés, em virtude da teoria do risco, pode ser incerto, o que é de difícil constatação.

Ainda nessa linha, constata-se que a lesão individual é sempre atual, permanente e clara. Possui, ainda, a característica da anormalidade. 0 dano ambiental, por outro lado, pode ser transtemporal, além de ser cumulativo de geração para geração. Diferentemente da tradicional, a lesão ambiental pode ser oriunda uma anormalidade, mas há possibilidade de existir uma tolerância social do dano.

Outro ponto que merece observação é o nexo de causalidade. Em relação à lesão clássica, visualiza-se que, por possuir elementos certos, é mais fácil a comprovação do liame causal. Quando se trata do dano ambiental, como se viu anteriormente, o ordenamento jurídico brasileiro adota a teoria da responsabilidade civil objetiva, dispensando, pois o elemento da culpa do agente. No entanto, resta comprovar o nexo causal e o dano ocorrido.

Embora isso seja pacífico na doutrina e na jurisprudência, até mesmo por uma imposição normativa, ainda há dissensões sobre que fundamentos devem ser usados para aplicar a responsabilidade objetiva em matéria ambiental. O fato é causado por muitos agentes, com várias condutas cumulativas, de diferentes espaços físicos, o que dificulta a delimitação do nexo do dano ambiental. Além disso, como a lesão é difusa, com características transfronteiriças, definir o poluidor parece ser uma tarefa tormentosa.

Há uma corrente que defende uma responsabilidade mais abrangente, mais severa (teoria risco integral), e outros se posicionam de forma mais comedida (teoria do risco-proveito e teoria do risco criado). A última sustenta que a responsabilidade, mesmo sem culpa, pode ser excluída em situações de força maior, caso fortuito e fatos de terceiros. ${ }^{26}$

A teoria da responsabilidade objetiva integral, como se vê, não admite nenhuma excludente de responsabilidade, o que fortalece o instituto. 0 dano ao meio ambiente não pode restar, em hipótese alguma, irreparado, devendo ser restaurado de forma mais integral possível. Não se pode pensar senão em uma malha bem apertada, capaz de enredar todos os responsáveis, de forma solidária, pelo prejuízo ao meio ambiente. ${ }^{27} \mathrm{~A}$ responsabilidade objetiva, segundo Barros, constitui o penúltimo estágio da evolução da responsabilidade ambiental, que se iniciou com a irreparabilidade e culmina com a responsabilidade objetiva integral. ${ }^{28}$

${ }^{26}$ São as típicas excludentes da responsabilidade. Segundo Cavalieri, o fato de terceiro ocorre quando terceiro, vítima ou não, é causa exclusiva do evento; força maior e caso fortuito, equiparados pelo Código Civil de 2002, são aqueles fatos necessários, cujos efeitos não se poderiam evitar, impedir. Ainda de acordo com o autor, distingue-se força maior de caso fortuito ao dizer que o primeiro se caracteriza pela inevitabilidade - os chamados acts of god ou fatos da natureza - enquanto o último caracteriza-se pela imprevisibilidade. CAVALIERI FILHO, Sergio. Programa de Responsabilidade civil. 8.ed. São Paulo: Atlas, 2008, p. 64 a 66.

${ }_{27}^{27}$ FERRAZ, Sérgio. Responsabilidade civil por dano ecológico. Revista de Direito Público, São Paulo, v. 49, n.50, p. 58.

${ }^{28}$ BARROS, Wellington Pacheco. Curso de Direito Ambiental. 2. ed. São Paulo: Atlas, 2008, p. 224 
0 empreendedor deve suportar todos os riscos inerentes à atividade potencialmente poluidora que desenvolve, haja vista que seria injusto que o dano ambiental pesasse sobre a sociedade. Apenas cabe determinar um provável liame entre o dano e o possível poluidor, não podendo excluir sua responsabilidade, invocando caso fortuito ou força maior. Caso tais excludentes fossem admitidas, poder-se-ia ter uma situação em que não houvesse nenhum responsável pelo prejuízo ambiental, que restaria irreparado. Aponte-se, outrossim, a irrelevância da licitude da atividade desenvolvida para a obrigação de reparar, pois a licença ambiental não é um salvo-conduto para poluir impunemente.

Notadamente, apesar das discussões em torno do tema, ainda passível de uniformização, o que se deve perceber é que o nexo causal da lesão ambiental não pode ser engessado, exatamente porque há situações em que a delimitação é difícil, e até impossível, o que acarretaria na impunidade dos poluidores. Basta fazer um rápido levantamento das defesas apresentadas pelos empreendedores em processos judiciais para verificar que, em matéria ambiental, a tese se sustenta no rompimento do nexo causal. Sobre o tema, observa Archer que "a prova do nexo de causalidade entre a conduta do lesante e o dano é um dos principais obstáculos a transpor pelo lesado no âmbito da efectivação jurisdicional da responsabilidade civil por dano ambiental".29

Ainda na mesma lógica, constata-se que a comprovação do dano tradicional é mais fácil de ser realizada, enquanto a prova da lesão ambiental, por conta de toda a sua complexidade, necessita de instrumentos mais flexíveis, como a verossimilhança e a probabilidade, dentre outros.

Esse "afrouxamento" do liame da causalidade e da prova do dano ambiental é decorrente do princípio da solidariedade, que funda o Estado de Direito Ambiental, ao impor a repartição do custo da atividade, além de se retratar como um dever fundamental de proteção ao meio ambiente do próprio empreendedor. 0 princípio da precaução se revela, ainda, como um importante instrumento de amparo jurídico da responsabilidade civil quando se tratar do risco em abstrato.

Ao comparar as lesões, percebe-se, ainda, que o dano tradicional se sujeita aos prazos prescricionais previsto no Código Civil, enquanto o dano ambiental, exatamente por todas as suas peculariedades, possui a característica da imprescritibilidade.

Diante de toda a complexidade que permeia o dano ambiental, é necessário criar mecanismos que busquem reverter o déficit de controle do risco, o que faz do instituto da responsabilidade civil ambiental possuir novas funções. Ao tratar do tema, expõe Benjamin quatro funções: “a) compensação das vítimas; b) prevenção de acidentes; c) minimização dos custos administrativos do sistema; d) retribuição". ${ }^{30}$

Em relação à primeira tarefa, a compensação das vítimas do dano ambiental é uma técnica reparatória clássica. No entanto, referida função deve ser entendida também como forma de estimular a prevenção de danos futuros com caráter educativo e expiatório. ${ }^{31}$

A dimensão preventiva (incluindo também a precaucional) deve servalorizada nesse novo contexto funcional da responsabilidade civil ambiental. É mister, dessa forma, a preocupação com as questões que estão por vir, assim como uma tutela de reparação dos danos já ocasionados. Essa nova perspectiva da responsabilidade civil, segundo Benjamin, inclui a potencialidade do dano em sua pauta, pois atribui relevância aos fardos sociais que possam advir com o passar dos anos. ${ }^{32}$

${ }^{29}$ ARCHER, António Barreto. Direito do Ambiente e Responsabilidade Civil. Coimbra: Almedina, 2009, p. 63. ${ }^{30}$ BENJAMIN, Antonio Herman V. A Responsabilidade civil pelo Dano Ambiental no Direito Brasileiro e as Lições do Direito Comparado. Disponível em: 〈http://bdjur.stj.gov.br/dspace/bitstream/2011/8632/3/A_Responsabilidade_Civil.pdf $>$. Acesso em: 20. ago. 2007, p. 15.

${ }^{31}$ Ibid., p. 15.

${ }^{2}$ Ibid., p. 16 
Ao analisar a legislação portuguesa, Sendim ilustra que os institutos da preservação e da restauração do dano ecológico são as principais ideias vinculadas ao direito de responsabilidade ambiental. Nesse diapasão, sustenta o autor que o sistema de responsabilidade por danos ambientais recebe a função específica de garantir a conservação dos bens ambientais juridicamente protegidos. ${ }^{33}$

Os princípios estruturantes do Estado de Direito Ambiental são utilizados na aplicação da responsabilidade civil. Sobre o tema, expõe Aragão que "a prossecução dos fins de melhoria e da qualidade de vida, com justiça social e ao menor custo, seria muito mais eficaz se cada um destes princípios se especializasse na realização dos fins para os quais está natural e originalmente mais vocacionado". ${ }^{34}$

Notadamente, é necessária uma visão integrada dos princípios estruturantes do Estado de Direito Ambiental que exercerão importante papel da materialização das novas funções da responsabilidade civil por dano ecológico. São utilizados, por conseguinte, em suas dimensões instrumentais e materiais, de acordo com a proposta de uma Hermenêutica Jurídica Ambiental.

Uma questão que se coloca, em termos teóricos e práticos, é: como compatibilizar a segurança jurídica com o princípio da precaução diante da implementação do instituto da responsabilidade civil por dano ambiental? Parece que esse é um dos grandes desafios do jusambientalismo atual.

Em virtude da sociedade do risco, o princípio da precaução começa a tomar formas mais profundas e complexas ao invadir todos os ramos do Direito. Se conceitos como certeza e verdade tomam novas dimensões em virtude da necessidade de um gerenciamento preventivo do risco, a própria essência de segurança jurídica, um dos pilares do Estado de Direito, também assume uma nova roupagem.

Nessa mesma senda, é combatível a existência de um direito adquirido a poluir, vale dizer, é descabido qualquer requerimento de indenização por se exigir do empreendedor o estancamento da poluição. Tal direito, consoante Benjamin, inexiste mesmo na hipótese de o Poder Judiciário ou Executivo decidir pelo encerramento das atividades de determinado estabelecimento. ${ }^{35}$

Os riscos e os danos ambientais fazem parte de uma complexa realidade no mundo pós-moderno. Delimitar o dano ambiental, como visto, ultrapassa as fronteiras do Direito, assim como a construção de uma gestão preventiva efetiva. Apesar de ser algo tão sólido e próximo da sociedade, a lesão é de difícil configuração teórica e prática, além de questões polêmicas em torno da sua reparação.

Uma perspectiva positiva está na sustentabilidade forte ${ }^{36}$, ao impor que o princípio da precaução pode autorizar o Judiciário, o Legislativo e até mesmo a Administração Pública quando tratar do licenciamento ambiental, rever atos, decisões e situações jurídicas anteriores, protegidos, inicialmente, sob a mácula do ato jurídico perfeito, da coisa julgada e do direito adquirido, como preceitua o art. 5ํㅡ. XXXVI, da Constituição Federal de 1988. Entre os mecanismos de efetivação do Direito Ambiental, faz-se referência à inversão do ônus da prova que, nas ações ambientais, incumbiria ao poluidor. ${ }^{37}$

\footnotetext{
33 SENDIM, José de Sousa Cunhal. Responsabilidade civil por danos ecológicos: da reparação do dano através da restauração natural. Coimbra: Coimbra Editora, 1998 p. 167.

${ }^{34}$ ARAGÃO, Maria Alexandra de Sousa. O princípio do poluidor-pagador: pedra angular da política comunitária do ambiente. Coimbra: Coimbra Editora, 1997. (Studia Ivridica, 23),op. cit., p. 218.

35 BENJAMIN, Antônio Herman. Constitucionalização do ambiente e ecologização da Constituição brasileira. In: LEITE, José Rubens Morato; CANOTILHO, José Joaquim Gomes (orgs.). Direito constitucional ambiental brasileiro. 2. ed. São Paulo: Saraiva, 2008, p. 126.

${ }^{36}$ LEITE; BELCHIOR, op. cit., p. 70.

37 FIORILLO, op. cit., p. 101.
} 
Referidos institutos não podem ser absolutos e imutáveis quando se trata do direito ao meio ambiente sadio, haja vista que as incertezas científicas são incompatíveis com conceitos engessados. A matéria ambiental deve ser analisada por uma perspectiva holística, haja vista que os processos ecológicos constituem-se como interdependentes e integrados.

Como se vê, a relativização da coisa julgada, do direito adquirido e do ato jurídico perfeito, como mecanismo de proteção do meio ambiente, encontra-se intrinsecamente relacionada à teoria do risco. Referidas garantias fundamentais encontram guarida na segurança jurídica, valor fundante do Estado de Direito Ambiental manifestado do princípio da juridicidade.

Na colisão entre os princípios do Estado de Direito Ambiental, a destacar o valor segurança jurídica, devem ser utilizadas as técnicas hermenêuticas de colisão entre os direitos fundamentais mediante a aplicação dos princípios da ponderação (bens, valores e interesses) e, por conseguinte, da proporcionalidade (meios e medidas) para buscar, de forma equilibrada, a proteção jurídica do meio ambiente.

Pode-se afirmar, de forma sintética, que as novas funções da responsabilidade civil ambiental englobam a prevenção e precaução do dano, que inibem a ação agressiva sobre o meio; a internalização dos custos ambientais; a pedagógica; o encorajamento dos investimentos da empresa e desenvolvimento para aumentar o conhecimento e melhorar a tecnologia; o fomento de atitudes mais responsáveis por parte dos poluidores; e, ainda, a restrição da instalação de empresas irresponsáveis instaladas no país.

Não há dúvida que a tutela preventiva do dano ambiental como medida prioritária em relação à reparação é um avanço na ordem jurídica ambiental. No entanto, as dificuldades se encontram na efetivação de referidos instrumentos que se tornam um grande desafio aos operadores do Direito Ambiental. Em um âmbito teórico, parece que a doutrina se mostra sensível, aberta e comprometida com a complexidade do dano ambiental. Entretanto, a previsão normativa e o embasamento doutrinário não são suficientes, pois a eficácia social da norma jurídica é condicionada, muitas vezes, aos aplicadores do Direito Ambiental, aqui incluindo os magistrados e os administradores públicos em geral. Mas a atenção maior, de forma inconteste, é voltada para a jurisprudência que pode (e deve) exercer uma tarefa fundamental na solidificação e efetivação de todas as peculiaridades que circundam os riscos e danos ambientais.

5 Riscos e danos ambientais na jurisprudência do Superior Tribunal de Justiça: uma análise a partir da Hermenêutica Ambiental

Discutidos os fundamentos da complexidade da responsabilidade civil por dano ambiental à luz da teoria da sociedade de risco e a necessidade de uma Hermenêutica Jurídica específica para lidar com as demandas do emergente Estado Ecológico, passa-se a analisar, no último tópico deste trabalho, cinco decisões do STJ com o objetivo de demonstrar a evolução do Direito Ambiental Brasileiro.

5.1 REsp 1.094.873 / SP: a proibição de queimadas de palha de cana-de-açúcar

Trata-se originariamente de ação civil pública ajuizada pelo Ministério Público do Estado de São Paulo com o objetivo de proibir queimada de palha de cana-de-açúcar como método preparatório da colheita desse insumo para a proteção do meio ambiente e da saúde dos trabalhadores que fazem o corte da planta. Além disso, o MP pede que sejam condenados os infratores ao pagamento da indenização correspondente a 4.936 litros de álcool por alqueire queimado. ${ }^{38}$

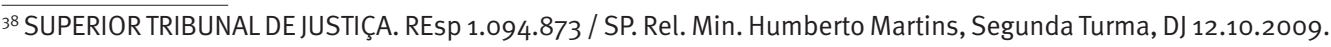


A sentença julgou procedentes todos os pedidos, tendo sido mantida pelo Tribunal a quo. Ainda inconformada, a parte recorreu ao STJ alegando que a decisão havia violado 0 art. 27, parágrafo único, da Lei n. 4.771/65 (que criou o Código Florestal brasileiro). Ao analisar o caso, percebe-se que a questão principal se baseia na interpretação do referido dispositivo.

Em uma leitura inicial, constata-se que o mesmo próbe o uso de fogo em florestas e outras formas de vegetação, mas prevê uma exceção: autoriza o emprego de fogo se peculiaridades locais ou regionais justificarem tal prática em atividades agropastoris e florestais. Nesse caso excepcional, a lei ressalva que deve haver permissão do Poder Público para a realização da queimada.

Nas razões jurídicas apresentadas no recurso, os produtores desenvolveram uma interpretação extensiva do Código Florestal, no sentido de que o art. 27, ora em pauta, abrangeria não apenas as queimadas relativas a atividades culturais de comunidades protegidas, mas também práticas comerciais organizadas e estruturadas para a produção de insumos em massa.

Apesar de existirem julgamentos anteriores no âmbito do STJ que priorizam questões meramente econômicas das queimadas ${ }^{39}$, os fundamentos não foram acolhidos pelos ministros. Ao utilizar alguns precedentes favoráveis da Corte Especial $4^{40}$, o relator, ministro Humberto Martins, destacou a necessidade de o desenvolvimento ser sustentável. Assim, observou o ministro que atualmente existem medidas tecnológicas que podem substituir a queimada sem inviabilizar a atividade econômica da indústria, preocupando-se, pois, com a sustentabilidade, marco axiológico do Estado de Direito Ambiental.

Ponto interessante de observar é que o relator, ao abordar a exceção prevista no art. 27 do Código Florestal, explica que a teleologia normativa é no sentido de compatibilizar o meio ambiente e a cultura, dois valores protegidos pelo constituinte. Notadamente, observou o ministro que "a interpretação do dispositivo não pode abranger atividades agroindustriais ou agrícolas organizadas porque, quando há formas menos lesivas de exploração, o interesse econômico não pode prevalecer sobre a proteção ambiental". ${ }^{41}$

Por fim, é de se destacar a importância da transdisciplinariedade em matéria ambiental e, por conseqüência, em relação à Hermenêutica específica para lidar com as normas que versam sobre Direito Ambiental. Segundo o ministro Martins:

[...] a interpretação das normas que tutelam o meio ambiente não comporta apenas, e tão-somente, a utilização de instrumentos estritamente jurídicos. [...] As ciências relacionadas ao estudo do solo, ao estudo da vida, ao estudo da química, ao estudo da física devem auxiliar o jurista na sua atividade cotidiana de entender o fato lesivo ao Direito Ambiental. $4^{2}$

Como se vê, o problema é muito maior do que se pode imaginar. Não é o Direito que irá resolver a complexidade ambiental. Não, pelo menos, sozinho. A questão ambiental é obrigatoriamente interdisciplinar, na medida em que se agrava por conta do risco e da crise civilizacional, de cunho global.

Nessa linha, o relator cita estudos científicos acerca do tema que comprovam que a queima da palha da cana-de-açúcar é notoriamente danosa à saúde e ao meio ambiente, em virtude da liberação de gases de efeito estufa (GEE) além de outros nocivos à saúde não apenas do homem, mas de várias espécies de fauna e flora.

\footnotetext{
${ }^{38}$ SUPERIOR TRIBUNAL DE JUSTIÇA. REsp 1.094.873 / SP. Rel. Min. Humberto Martins, Segunda Turma, DJ 12.10.2009. 39 SUPERIOR TRIBUNAL DE JUSTIÇA. REsp 294.825 / SP, Rel. Min. José Delgado, Primeira Turma, DJ 28.10.2003.

$4^{\circ}$ SUPERIOR TRIBUNAL DE JUSTIÇA. REsp 439.456 / SP, Rel. Min. João Otávio de Noronha, Segunda Turma, julgado em 03.08.2006, DJ 23.06.2007, p. 217. SUPERIOR TRIBUNAL DE JUSTIÇA. REsp 161.433 / SP, Rel. Min. Ari Pargendler, Segunda Turma, julgado em 14.12.1998, DJ 14.12.1998, p. 210. SUPERIOR TRIBUNAL DE JUSTIÇA. REsp 345.971 / SP, Rel. Min. Francisco Falcão, DJ 06.03.2006.

${ }_{41}$ Informativo do STJ. Disponível em http://www.stj.jus.br/portal_stj/publicacao/engine.wsp?tmp.area=398\&tmp. texto=93100. Acesso em 28. set. 2009.

${ }^{42} \mathrm{lbid}$.
} 
In casu, à luz de uma Hermenêutica Ambiental, contata-se que os ministros utilizaram, embora de forma não expressa, o princípio da ponderação para sopesar os valores, bens e interesses envolvidos. Vê-se que os interesses difusos e coletivos referentes ao equilíbrio ambiental e à saúde foram priorizados em relação aos interesses individuais em uma balança hipotética. Ademais, os princípios da solidariedade, da razoabilidade, da precaução e da prevenção também podem servir de instrumentos para fundamentar a decisão em questão.

Nesse sentido, ao negar provimento ao agravo regimental de forma a implementar a sustentabilidade, marco axiológico do Estado de Direito Ambiental, a Segunda Turma do STJ mostrou-se avançar no amadurecimento dos postulados do Estado Ecológico das peculiaridades em torno do dano ambiental.

\subsection{REsp 972.902 / RS: a inversão do ônus da prova em matéria ambiental}

O Ministério Público do Rio Grande do Sul ajuizou ação civil pública objetivando a reparação de dano ambiental de uma empresa de borracharia. 0 recurso especial foi interposto pelo MP com intuito de obter a inversão do ônus da prova, pedido negado pelas instâncias inferiores.

Acerca do tema, importante observar trecho das razões jurídicas levantadas pelo Parquet estadual:

A inversão do ônus da prova decorre diretamente da transferência do risco para o potencial poluidor. Em virtude do acolhimento da teoria do risco integral, defendida por Antônio Herman Benjamin, José Afonso da Silva, Fábio Dutra Lucarelli, Nelson Nery Júnior e Edis Milaré, dentre outros, transfere-se para o empreendedor todo o encargo de provar que sua atividade não enseja riscos para o meio ambiente, bem como a responsabilidade de indenizar os dados causados, bastando que haja um nexo de causalidade provável entre a atividade exercida e a degradação..$^{43}$

Como se vê, a inversão do ônus da prova ocorre diante da relevância do objeto jurídico protegido e das dificuldades inerentes ao dano ambiental. Referida interpretação se dá diante da aplicação dos princípios da precaução, da prevenção e da responsabilização que estruturam o Estado de Direito Ambiental.

O princípio precaução impõe um meio de gerenciamento de riscos, cujo controle de aplicação, segundo Aragão, dá-se por meio de "princípios gerais de gestão de riscos: proporcionalidade, não-discriminação, coerência, análise das vantagens e encargos e análise de evolução científica". ${ }^{44}$ Revela-se como "uma garantia material de realização efectiva do princípio do nível mais elevado de protecção ecológica”45. (Destaque no original)

Além da dimensão material, o citado princípio também conquista um viés instrumental, ao impor a utilização de medidas e de técnicas disponíveis para minimizar o dano ambiental, não obstante sua previsibilidade. No âmbito de uma Hermenêutica Jurídica Ambiental, o princípio da proporcionalidade é aplicado em parceria com o princípio da precaução, em virtude de ambos buscarem medidas e meios equilibrados na captação de uma solução que seja mais conveniente para efetivar o Estado de Direito Ambiental.

É viável a utilização do in dubio pro ambiente ou interpretação mais amiga do ambiente, expressão esta utilizada por Canotilho, o que não acarreta em uma visão radical na defesa do meio ambiente. Aponta o doutrinador lusitano que o princípio da interpretação mais amiga do ambiente, "como expresso ou ratio da maioria das normas jurídicas aplicáveis ao caso, é inatacável, não goza, em termos apriorísticos e abstractos, de uma prevalência absoluta”. ${ }^{46}$

\footnotetext{
43 SUPERIOR TRIBUNAL DE JUSTIÇA. REsp 972.902 / RS. Rel. Min. Eliana Calmon, Segunda Turma, DJ 20.11.2009. ${ }_{4}$ ARAGÃO, Maria Alexandra de Sousa. O princípio do nível elevado de protecção ecológica: resíduos, fluxos de materiais e justiça ecológica. Tese de Doutoramento. FDUC. Coimbra: 2004, p. 264.

45 Ibid., p. 265.

${ }^{46}$ CANOTILHO, José Joaquim Gomes. Protecção do ambiente e direito de propriedade: crítica de jurisprudência ambiental. Coimbra: Coimbra, 1995, p. 83.
} 
Em outras palavras, não significar dizer que o direito ao meio ambiente sadio sempre irá prevalecer em relação aos demais, pois deve haver um equilíbrio entre os princípios e valores fundantes como sugere um antropocentrismo alargado pautado em uma ética solidária e intergeracional. Basta pensar no valor sustentabilidade, que impõe o equilíbrio do tripé formado pelo desenvolvimento econômico, pela equidade social e pelo meio ambiente sadio, além da concepção antropocêntrica alargada. Aqui, recorre-se ao princípio da razoabilidade que guiará o intérprete na utilização da precaução e, em especial, na interpretação in dubio pro ambiente.

Não é demais lembrar que o julgador não poderá formular sua decisão baseada exclusivamente no princípio da precaução. Toda a principiologia da hermenêutica ambiental deve ser analisada, a fim de evitar arbitrariedades e conseqüências ainda mais graves. Notadamente, o princípio da razoabilidade, e demais técnicas específicas como a proporcionalidade, exercem importante papel no procedimento da aplicação da precaução. Na mesma linha, referida argumentação fundamenta a delimitação do quantum em ações de responsabilidade civil de dano ambiental.

Outro princípio que estrutura do Estado de Direito Ambiental é o da prevenção. Como o próprio nome sugere, seu objetivo é a adoção de políticas de gerenciamento e a proteção do meio ambiente, de forma prévia aos processos de degradação ambiental. Como se vê, é perceptível que prevenção e precaução estão intimamente relacionadas. Milaré sustenta que o último se encontra dentro do primeiro, haja vista que a prevenção, por ter um caráter genérico, engloba a precaução. 47

Extrai-se que a prevenção é passível de aplicação quando se sabe quais as conseqüências antes de se iniciar e de se prosseguir com determinada atividade. Aplica-se em situações onde existe a comprovação científica do nexo causal, possuindo a finalidade de eliminar os perigos quando o mesmo puder ser verificado antecipadamente, para coibir a degradação do meio ambiente, antes que a mesma se concretize.

Já o princípio da precaução manifesta-se quando não se sabe ao certo qual o resultado da prática de determinado ato, haja vista não existir a certeza científica do resultado. Entretanto, a falta de certeza do nexo causal não pode ser motivo de escusa para não se tomar atitudes eficazes com o objetivo de impedir a degradação ambiental.

É importante destacar que, independente de ser prevenção ou precaução, o intérprete há de estar pautado em uma gestão do risco de forma prévia, antecipatória. Como diz o velho jargão popular, "é melhor prevenir do que remediar". De qualquer forma, defende-se o caráter amplo da prevenção que engloba, por conseqüência, a precaução. Trata-se, em geral, de uma atuação preventiva do risco ambiental.

Mister salientar que ambos os princípios, prevenção e precaução, podem ser aplicados de forma concomitante, pois, apesar de objetivos distintos, os dois atuam como instrumentos antecipatórios na gestão do risco ambiental. A grande diferença verificada pela Hermenêutica Jurídica Ambiental é que a moldura deôntica da prevenção contém mais premissas vinculativas de preenchimento pelo intérprete do que em relação à precaução, cujo papel interpretativo para delimitar e fixar seu alcance é bem maior, haja vista esta possuir maior vaguidade semântica por lidar com um risco abstrato.

Utiliza-se, ainda, no caso tela, o princípio da responsabilidade, cuja premissa é: quem causa dano ao meio ambiente deve por ele responder. Vê-se, ademais, que a responsabilização é corolária da gestão antecipatória do risco ambiental, haja vista que, caso a possibilidade de reparação do dano não existisse, de nada adiantariam as ações preventivas e precaucionais.

${ }_{47}$ MILARÉ, Edis. Direito do ambiente: a gestão ambiental em foco. Doutrina, jurisprudência, glossário. 5. ed. São Paulo: Revista dos Tribunais, 2007, p. 118. 
A relatora, Ministra Eliana Calmon, utiliza-se claramente dos princípios de Direito Ambiental como instrumento hermenêutico, ao expor que:

[...] a análise sobre o ônus da prova, em ação coletiva por dano ambiental, deve ser dirimida pela interpretação das leis aplicáveis ao mencionado instrumento processual à luz dos princípios norteadores do Direito Ambiental. Isso porque, em regra, a inversão do ônus probatórios deve assentar-se exclusivamente em disposição expressa de lei. Mas, no presente caso, essa inversão encontra fundamento também em princípios transversais ao ordenamento jurídico, quais sejam, os princípios ambientais. $4^{8}$

Percebe-se que o entendimento da ministra está em perfeita consonância com o póspositivismo, na medida em que confere normatividade aos princípios jurídicos. Interessante mencionar que os princípios não precisam estar positivados de forma expressa na ordem jurídica para ter validade. Não há como o rol dos princípios ser taxativo, na medida em que eles sinalizam os valores e os anseios da sociedade, que estão em constante transformação. Por conseguinte, limitá-los à ordem jurídica positiva é impossível, pois não se tem como engessar a sociedade.

Os princípios nascem de um movimento jurídico de indução, ou seja, do individual para o geral, emanando a justiça. A doutrina e, em especial, a jurisprudência realizam referido processo de abstração na teorização e aplicação do Direito. Vê-se que, neste momento, eles já são normas jurídicas, condensando valores e orientando o intérprete, uma vez que o Direito não só a lei, como queria o positivismo jurídico. Com a sua reiterada aplicação e permanência no seio social, o legislador, a fim de lhe garantir também segurança jurídica, ampara-o em uma lei, ou na própria Constituição, por meio de um raciocínio jurídico por dedução.

Por outro lado, o art. 333 do Código de Processo Civil brasileiro assevera que às partes caberá a prova de suas alegações. No entanto, em face de todas as peculiaridades que permeiam a problemática do dano ambiental, como discutido no decorrer desse trabalho, a Min. Eliana, em seu voto, aponta a possibilidade de inversão do ônus da prova em processos ambientais, apesar de ausência expressa de tal mandamento normativo. Aplica-se, por analogia, o art. 6ํㅡ, VIII, do Código de Defesa do Consumidor, que compõe o microssistema de direito coletivo, ao prever a possibilidade de inversão do ônus da prova pelo juiz, desde que presentes a verossimilhança das alegações ou a hipossuficiência do autor.

Assim, ao utilizar os princípios da precaução, da prevenção e da responsabilização, a Segunda Turma, seguindo a relatora, entendeu que, nas ações civis ambientais, o caráter público e coletivo do bem jurídico tutelado - e não eventual hipossuficiência do autor da demanda em relação ao réu - conduz à conclusão de que alguns direitos do consumidor também devem ser estendidos ao autor daquelas ações, pois essas buscam resguardar (e muitas vezes reparar) o patrimônio público coletivo consubstanciado no meio ambiente.

Notadamente, tratando-se de dano ambiental, o juiz teria o "poder-dever" de, no caso concreto, inverter o ônus da prova, não em prol do autor, mas da coletividade em geral, que tem o direito de ser informada se há ou não possível prática lesiva ao meio ambiente. Constata-se que o fundamento da inversão do ônus da prova em matéria ambiental se baseia na aplicação do princípio da precaução, haja vista que seu objetivo primordial é evitar o dano ambiental, não sendo necessária, para tanto, a sua comprovação científica; e, ainda, do princípio da solidariedade, que obriga o empreendedor a comprovar, antecipadamente, que a implantação de sua atividade não causará significativa degradação ao meio ambiente. A inversão do ônus da prova ambiental integra o gerenciamento preventivo do risco ecológico, contribuindo, portanto, para a efetivação do Estado de Direito Ambiental.

Conclui-se, pois, que ao interpretar o art. 6ํㅡ, VIII, da Lei n. 8.078/1990 (que cria o Código de Defesa do Consumidor) cumulado com o art. 21 da Lei n. 7.347/1985, sob a lente da gestão

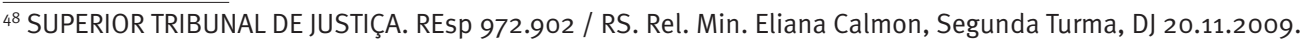

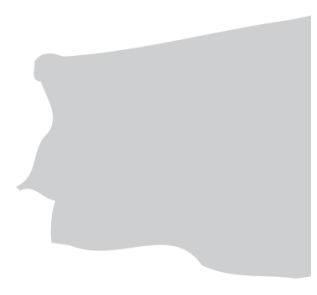


preventiva (incluindo a precaução) do dano ambiental, os ministros justificaram a inversão do ônus da prova, transferindo para o empreendedor da atividade potencialmente lesiva o ônus de demonstrar a segurança da atividade. Nesse esteio, o entendimento da Segunda Turma, mais uma vez, releva-se de sensível às particularidades do dano ambiental.

\subsection{REsp 769.753 / SC: a remoção de empreendimento turístico situado em Porto Belo (SC)} diante da ilegalidade da licença ambiental e o fato consumado

Em setembro de 1993, a União ajuizou ação civil pública com o intuito de demolir obra de hotel situada em terreno marinho na praia de Porto Belo - SC, devido à lesividade ao patrimônio público e ao meio ambiente. Pediu, ademais, a anulação do auto pelo qual o município autorizou a construção e a cassação do direito de ocupação do empreendedor, Mauro Antônio Molossi.

Os pedidos foram julgados improcedentes em primeira instância. O Tribunal Regional Federal da $4^{-}$região, em sede de apelação, alterou a sentença sob o fundamento de que os interesses econômicos devem estar em consonância com o respeito à natureza e aos ecossistemas, haja vista que o objetivo é um desenvolvimento econômico vinculado ao equilíbrio ambiental. Em outras palavras, o Tribunal a quo decidiu, em parte, de acordo com o desenvolvimento sustentável, instrumento para se buscar a sustentabilidade para as presentes e futuras gerações.

No que concerne ao recurso interposto pelo Ministério Público Federal e pela União, o objetivo é obrigar o proprietário e o município de Porto Belo a promover a remoção do empreendimento. Pedem, ainda, que haja condenação solidária referente à remoção dos respectivos resíduos e à recuperação do dano ambiental.

O proprietário, Mauro Molossi, alega que o plano de gerenciamento costeiro, que confere competência aos estados e aos municípios para legislar sobre área costeira foi devidamente observado. Aponta, ainda, que a dispensa do estudo prévio de impacto ambiental e do respectivo relatório foi realizada de forma implícita. Assim, sustenta o empreendedor que as exigências técnicas estabelecidas pelo órgão municipal ambiental possuem a mesma finalidade do relatório de impacto ambiental, satisfazendo, pois, referido procedimento administrativo ambiental.

De acordo com o relator, Ministro Herman Benjamin, é indiscutivel que a obra foi construída em promontório, um acidente geográfico localizado no litoral no continente. Destaca, ademais, o ministro que a licença prévia foi concedida ilegalmente, uma vez que viola a legislação infraconstitucional, assim como a ordem jurídica constitucional. Nesse sentido, o ato administrativo não pode ser utilizado sem o devido estudo de impacto ambiental. Observa o ministro:

[...] o licenciamento prévio foi concedido sem a observância da legislação federal regente, que exige a elaboração do Estudo de Impacto Ambiental e, conforme observado pela decisão recorrida, em desacordo com a legislação local, que classifica os promontórios como zona de preservação permanente erigida à categoria de área non aedificandi. 49

Da mesma forma como verificado em julgado anterior, os princípios da precaução, da prevenção e da responsabilidade são utilizados como instrumentos hermenêuticos para lidar com as particularidades do processo.

In casu, percebe-se que o administrador público municipal falhou na adoção de política pública ambiental, na medida em que dispensou o estudo prévio de impacto ambiental e seu respectivo relatório para a concessão da licença. Nesse esteio, cabe a intervenção do

49 SUPERIOR TRIBUNAL DE JUSTIÇA. REsp 769.753 / SC. Rel. Min. Herman Benjamin, Segunda Turma, julgado em 08.09.2009. Até o desfecho deste trabalho, o acórdão ainda não havia sido publicado. 
Judiciário, que utilizará a Hermenêutica Jurídica Ambiental de forma a captar sentidos convenientes com o Estado Ecológico.

A Segunda Turma do STJ, ao seguir o voto do relator, negou provimento ao recurso do particular e deu provimento aos recursos da União e do Ministério Público Federal no sentido de demolir o empreendimento e condenar o empreendedor e o município de Porto Belo, solidariamente, no que concerne à responsabilidade pelo dano ambiental.

É interessante destacar que o fato do hotel estar ou não em atividade, gerar ou não empregos e desenvolvimento econômico e turístico para a região, foi irrelevante para o julgado. Até porque se constatou um vício de nulidade no ato de jurídico que concedeu a licença administrativa. Percebe-se que o princípio da prevenção não foi observado, na medida em que não se realizou o estudo prévio de impacto ambiental e seu respectivo relatório de forma a fundamentar 0 ato da licença.

Ademais, houve violação ao princípio da precaução em sua dimensão material, haja vista que é notório o dano em potencial e em abstrato na atividade empreendedora. No entanto, o princípio da precaução também pode ser utilizado aqui no seu caráter instrumental para orientar o intérprete. Não importa o momento ou o fator do tempo. A concretização da precaução deve ser realizada em virtude do dano em abstrato. À medida que a ciência avança, novas descobertas são reveladas, tornando potencialmente nocivas práticas antigas já permitidas. É comum a Administração Pública admitir, em um primeiro momento, atividades e execução de serviços e, logo em seguida, contatar que referida liberação acarretou desequilíbrio ambiental, que não se tratou, especificamente, do presente caso.

O magistrado pode efetuar o controle de políticas públicas ambientais, observando as limitações políticas e jurídicas previstas pela tripartição das funções públicas. Caso um dos "poderes" não cumpra com sua função típica fixada pelo constituinte, caberá ao outro "poder" intervir de forma harmônica, desde que tenha legitimidade constitucional para tanto, seguindo os limites por ela impostos, e desde que seja para efetivar os direitos fundamentais, principalmente quando se trata do direito ao meio ambiente ecologicamente equilibrado, luz que irradia os demais direitos fundamentais.

Notadamente, é função típica do legislador formular as normas abstratas de conduta. 0 cumprimento dessas normas, por meio da administração pública, é tarefa típica do Executivo. Já a aplicação destas normas, mediante provocação, para compor os litígios, é o exercício da jurisdição..$^{50}$

A ordem jurídica ambiental é repleta de conceitos vagos, obscuros, indeterminados. Caberá ao intérprete (membro da Administração Pública) preencher as zonas cinzentas que lhe são próprios no que condiz, de forma mais evidente, aos atos de licenciamento ambiental. Segundo Krell, no ato de interpretação existem zonas cinzentas ("zonas de incerteza"), dentro das quais pode haver diferentes entendimentos sobre a questão da hipótese da norma ter sido ou não preenchida pelos fatos da realidade. Nessa zona de penumbra, há ampla liberdade do administrador público..$^{1}$

Uma Hermenêutica Jurídica Ambiental poderá auxiliar nesta tarefa, com vistas a buscar um conteúdo em sintonia com o Estado Ambiental. No entanto, é cada vez maior a sindicabilidade dos atos administrativos, em especial, dos atos administrativos discricionários. ${ }^{22}$

\footnotetext{
${ }^{50}$ TEIXEIRA, Sálvio de Figueiredo. A criação e realização do Direito na decisão judicial. Rio de Janeiro: Forense, 2003, p. 5. ${ }^{51}$ KRELL, Andreas J. Discricionariedade Administrativa e proteção ambiental: o controle dos conceitos jurídicos indeterminados e a competência dos órgãos ambientais - um estudo comparativo. Porto Alegre: Livraria do Advogado, 2004 .p. 41. ${ }^{52} \mathrm{Na}$ lição de Moraes, discricionariedade é “[...] a margem de liberdade de decisão, conferida ao administrador pela norma de textura aberta ${ }^{52}$, com o fim de que ele possa proceder, mediante a ponderação comparativa dos interesses envolvidos no caso específico, à concretização do interesse público ali indicado, para, à luz dos parâmetros traçados pelos princípios constitucionais da Administração Pública e pelos princípios gerais do Direito e dos critérios não positivados de conveniência e oportunidade”. MORAES, Germana de Oliveira. Controle Jurisdicional da Administração Pública. 2. ed. São Paulo: Dialética, 2004, p. 48.
} 
A atividade administrativa, no que tange às políticas públicas, deve estar ligada à efetivação dos direitos fundamentais, ou seja, ao satisfazer o interesse público, atingir o bem comum. Não se nega que ao administrador público cabe escolher quais as formas de se atingir essa efetividade, valendo-se, nesse caso, da discricionariedade que possui.

A doutrina do mérito administrativo dos atos discricionários, em um primeiro momento, defendia a sua total intangibilidade pelo Judiciário. Hoje, ao revés, na era do Direito por regras e por princípios, como impõe o pós-positivismo, o controle jurisdicional é bem mais amplo, na medida em que o administrador deve obediência não apenas às regras, mas também aos princípios. 0 agente público está vinculado, assim, ao princípio da juridicidade, um dos fundantes do Estado de Direito Ambiental.

Dessa forma, mesmo no ato discricionário, que dá margem de escolha do mérito administrativo (motivo e objeto), apesar de o administrador público não estar vinculado à lei, referido ato deve ser compatível com os princípios jurídicos, em obediência ao princípio da juridicidade (e não mais apenas legalidade). Aqui, ocorre o que a doutrina intitula de controle de juridicidade em sentido estrito ${ }^{53}$, vez que todos os atos, não importa se vinculado ou discricionário, devem estar em conformidade com os princípios jurídicos, à luz do princípio fundante da juridicidade do Estado de Direito Ambiental.

Assim, extrai-se que o referido julgado do STJ só faz ratificar a possibilidade do controle juridicional de políticas públicas em matéria ambiental, em consonância com o Estado de Direito Ambiental. Referida sindicabilidade diz respeito não apenas à legalidade do ato, mas também quando se tratar do controle de juridicidade, englobando, inclusive, o mérito administrativo.

Outro ponto importante a ser verificado na decisão é o repúdio à teoria do fato consumado pela qual pressupõe uma situação ilegal consolidada no tempo, em decorrência da concessão de liminar ou de ato administrativo praticado com algum vício de legalidade em virtude da segurança jurídica das relações advindas daquele ato.

No caso em tela, o empreendimento estava funcionando há anos, apesar da ilegalidade do ato de licença ambiental. Nessa linha, não era de se assustar se o entendimento da Corte fosse no sentido de manter o funcionamento do hotel, aplicando apenas multa ao particular, sob a alegativa do fato consumado. A responsabilidade surgiria, assim, em dose homeopática e quase invisível, em consonância com a irresponsabilidade organizada apontada por Beck.

Ocorre que, quando se trata de dano ambiental, sabe-se que sua restauração é praticamente impossível, o que impõe um gerenciamento preventivo do risco ambiental. O Estado de Direito Ambiental defende a sustentabilidade forte, na medida em que a problemática ambiental deve ter um peso diferenciado nas discussões hodiernas, inclusive no âmbito do Direito.

No entanto, em virtude da sociedade do risco, o princípio da precaução começa a tomar formas mais profundas e complexas ao invadir todos os ramos do Direito. Se conceitos como certeza, segurança e verdade tomam novas dimensões em virtude da necessidade de um gerenciamento preventivo do risco, a própria essência de segurança jurídica, um dos pilares do Estado de Direito, também assume uma nova roupagem.

Nesse esteio, a decisão ambiental, seja ela política ou judicial, deve ser integrada, pois as questões relacionadas ao meio ambiente requerem envolvimento de todos os agentes sociais e econômicos. Isso implica, por conseguinte, em duplo comando:

(1) necessária a observância, pelo poder público, dos princípios gerais de Direito Ambiental, quando do desenvolvimento e execução das distintas políticas públicas setoriais; (2) inafastável promoção, no âmbito dos estudos técnicos obrigatórios, de prévia identificação e avaliação de forma integrada e global dos riscos e impactos

${ }^{53}$ MORAES, op. cit., p. 49-50. 
potenciais relativos à instalação de empreendimentos e atividades, bem como importa considerar e avaliar os impactos decorrentes da adoção de políticas públicas e orientações legislativas. ${ }^{54}$

Por conta disso, a sustentabilidade forte impõe que o princípio da precaução pode autorizar o Judiciário, o Legislativo e até mesmo a Administração Pública quando tratar do licenciamento ambiental, rever atos, decisões e situações jurídicas anteriores, protegidos, inicialmente, sob a mácula do ato jurídico perfeito, da coisa julgada e do direito adquirido, como preceitua o art. $5^{\circ}, \mathrm{XXXVI}$, da Constituição Federal de 1988.

Referidos institutos não podem ser absolutos e imutáveis quando se trata do direito ao meio ambiente sadio, haja vista que as incertezas científicas são incompatíveis com conceitos engessados. A matéria ambiental deve ser analisada por uma perspectiva holística, haja vista que os processos ecológicos constituem-se como interdependentes e integrados.

Nessa linha, o voto relatado pelo Min. Herman Benjamin só comprova a tendência da Corte Especial de atender aos postulados do Estado de Direito Ambiental, em especial, a não recepção da teoria do fato consumado quando se tratar de dano ambiental.

\subsection{REsp 791.653 / RS: a condenação de dano moral por poluição sonora}

Trata-se, inicialmente, de ação civil pública ajuizada pelo Ministério Público do Estado do Rio Grande do Sul com o objetivo de condenação da empresa AGIP do Brasil S/A, ora ré, para se abster de utilizar jingle ou música, seja em seus veículos ou distribuidores para promoção de seus produtos até que de adeque à legislação municipal, sob pena de imposição de multa, bem como busca a condenação ao pagamento de indenização por dano moral ambiental oriundo de poluição sonora.

Nesse ínterim, foi editado o Decreto Municipal n. 11.477/96 que regula os decibéis permitidos no caso de poluição sonora, o que fez o juiz singular a extinguir o processo sem resolução do mérito por perda de objeto. Inconformado, o parquet estadual interpõe apelação sob a alegativa de que:

[...] a) um dos pontos da pretensão perdera seu objeto, por fato superveniente, entretanto, remanesceu o pedido de indenização por danos morais já consumados, decorrentes de poluição sonora; b) ante as provas fartas e contundentes acostadas nos autos, é de se reconhecer que a empresa exercia suas atividades irregularmente, causando danos e transtornos àquela comunidade, ensejando a indenização pleiteada $[. . .]^{55}$

Após o provimento da apelação, a empresa interpõe embargos de declaração, sustentando omissão no julgador acerca do que foi pedido, assim como julgamento extrapetita. Diante da rejeição dos embargos, a empresa interpôs recurso especial sob o fundamento do art. 535, Il, do Código de Processo Civil. ${ }^{56}$

A empresa alega em suas razões recursais que o Tribunal a quo apreciou somente parte dos pontos omissos elencados na peça de embargos de declaração por ocasião do julgamento e se manteve silente em relação a outras questões postas em sede de contestação, quais sejam:

a) não apreciação pelo Tribunal do Decreto Municipal n. 11.477/96 à luz dos arts. 23, inciso IV, 24, incisos VI e VIII, 30, incisos I e II, todos da Constituição Federal, e do art.

\footnotetext{
${ }^{54}$ Trecho retirado da petição de amicus curiae apresentada pela Federação das Entidades Ecologistas Catarinenses - FEEC e pelo Grupo de Pesquisa Direito Ambiental e Ecologia Política na sociedade de risco - GPDA/UFSC, nos autos da ADI 4252-1, que questiona a constitucionalidade de vários dispositivos da Lei nํ․ 14.675, de 13 de abril de 2009, que instituiu o Código Ambiental Estadual de Santa Catarina.

${ }_{55}^{5}$ SUPERIOR TRIBUNAL DE JUSTIÇA. REsp 791.653 / RS. Rel. Min. José Delgado, Primeira Turma, julgado em 06.02.2007. DJ 15.02 .2007$, p. 3 .

56 "Art. 535. Cabem embargos de declaração quando: [...] II - for omitido ponto sobre qual devia pronunciar-se 0 juiz ou o tribunal."
}

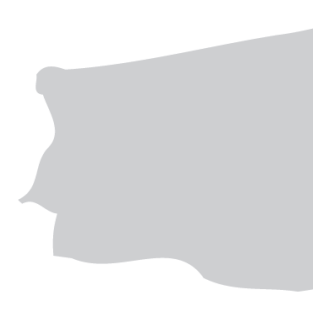

Juz 


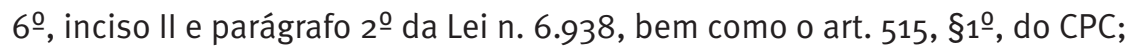

b) inadequação do Decreto Municipal como limitador de direito. Inconstitucionalidade do Decreto Municipal n. 11.477/96. O Princípio da Legalidade, consagrado no art. 5을 inciso II, da Carta Magna.

c) existência de omissão quanto ao fundamento do dano moral ambiental. Inexistência de coletividade. Apreciação do art. $1^{0}$ da Lei n. 7.347/85.57

Sustenta, por fim, a recorrente que as matérias não-apreciadas se tratam exatamente do mérito da demanda e invoca o recebimento e provimento do recurso especial. Em virtude do juízo negativo de admissibilidade, a ré interpõe agravo de instrumento ao STJ, o qual foi dado provimento e convertido em recurso especial, conforme decisão do relator. Destaca-se, ainda, que o parecer da Procuradoria-Geral da República foi pelo não provimento do recurso.

Ao analisar o recurso, o relator, Min. José Delgado, entende que não há omissão das instâncias inferiores. Destaca que na regular prestação da jurisdição não se exige que "todo e qualquer tema indicado pelas partes seja particularmente analisado, sendo suficiente a consideração das questões de relevo e essencialidade para o debate da controvérsia". ${ }^{8}$

Reconhece, nessa linha, o ministro a caracterização de dano moral pela empresa recorrente em razão da poluição sonora ensejadora de dano ambiental e, ainda, a obrigação decorrente de reparação dos prejuízos causados à população.

Entretanto, apesar de o STJ não ter discutido aspectos pontuais levantados na exordial recursal, percebe-se que a apreciação acerca da (in) constitucionalidade do Decreto Municipal, pela via difusa, não deve prosperar, na medida em que o decreto é uma norma jurídica secundária. Logo, segundo entendimento já pacificado no âmbito do Supremo Tribunal Federal, possíveis vícios de decreto em face da Constituição Federal não se tratam de ofensa direta, mas meramente reflexa, constituindo-se como vício de legalidade, pois seu fundamento de validade não é a Lei Maior, mas a lei regulamentada.59

Sobre a ausência de fundamentação do dano moral ambiental no ordenamento jurídico brasileiro levantada pela empresa, é preciso sustentar alguns apontamentos relevantes. De fato, não existe "norma" expressamente prevista que preveja o dano moral por ofensa ao meio ambiente. No entanto, o atual contexto do pós-positivismo traz que a ordem jurídica é formada não apenas por normas-regra, mas também por normas-princípio, cujo conteúdo é manifestado por valores. Assim, pode-se mudar a afirmação anterior: não há norma-regra no direito brasileiro que trate do dano moral ambiental. Mas quando se trata dos princípios, a situação é diferente.

Os princípios jurídicos, diferentemente das regras, contêm, em sua estrutura dêontica, relatos com maior grau de abstração, não apontam uma conduta específica a ser seguida, possuindo um âmbito de incidência amplo, e até indeterminável de situações. Os diretos previstos em um princípio são prima facie, não tendo o mesmo caráter de definitividade das regras. Tem conteúdo altamente axiológico, além do fato de que nem todos os princípios estão obrigatoriamente expressos. Seu rol, por conseguinte, é meramente exemplificativo, uma vez que surgem da própria realidade, em busca da justiça, captados por raciocínio jurídico indutivo (do individual para o geral).

Não há dúvida de que a atividade de julgar passa a ter uma importância maior no póspositivismo, na medida em que o Direito não se limita às regras jurídicas. 0 juiz não pode agir apenas por meio de raciocínios dedutivos, na lógica dos silogismos, como perdurou no positivismo. Com o retorno da Ética e da Moral ao Direito, o magistrado tem uma maior liberdade para proferir suas decisões.

\footnotetext{
57 SUPERIOR TRIBUNAL DE JUSTIÇA. REsp 791.653 / RS. Rel. Min. José Delgado, Primeira Turma, julgado em 06.02.2007. DJ 15.02 .2007 , p. 4.

${ }^{8}$ Ibid., p. 7.

${ }^{59}$ SUPREMO TRIBUNAL FEDERAL. ADI 264, Rel. Min. Carlos Velloso, DJ 25.08.1995.
} 
Tal fato decorre da normatização dos princípios e do papel que os valores passaram a exercer na ciência jurídica. Os princípios, como discutido anteriormente, não precisam estar positivados de forma expressa na ordem jurídica para tervalidade. Em verdade, os princípios jurídicos encontram guarida na expressão "princípios gerais do Direito", previstos na Lei de Introdução ao Código Civil. ${ }^{60}$ Mas o legislador, sabiamente, não os enumerou de forma taxativa, na medida em que não há possibilidade de se engessar a sociedade.

Como se vê, não há como o rol dos princípios ser exaustivo e limitado, pois eles sinalizam os valores e os anseios da sociedade, que estão em constante transformação. Por conseguinte, limitá-los à ordem jurídica positiva é impossível, pois não se tem como congelar a dinâmica social. A mesma lógica ocorre com os princípios de Direito Ambiental.

A norma, como se vê, traz uma estrutura lógica, cognoscente da conduta, estando, assim, formalizada. Por conta disso, a lógica jurídica não tem como deixar de ser formal exatamente pelo fato de suas estruturas serem aptas a acolher o objeto jurídico, que é uma espécie de ente deôntico (normativo).

Por outro lado, não há dúvida de que a interpretação e aplicação dos princípios jurídicos, assim como o preenchimento das molduras deônticas nas decisões judiciais, se não for feita de forma racional, poderá dar margem para subjetividade e arbitrariedade. Diante da inércia ou ineficiência do Executivo e do Legislativo, o Judiciário vem sendo cada vez mais procurado para a garantia da tutela jurisdicional de direitos, em especial, lides que envolvam a temática do dano ambiental.

No caso em tela, diante de lacuna específica de regra jurídica sobre o dano moral ambiental, lança-se mão dos princípios fundantes e estruturantes do Estado de Direito Ambiental que, além de serem os alicerces do emergente paradigma estatal, possuem função normativa primária, como propaga o pós-positivismo. Ademais, aplica-se, por indução, a normatização existente acerca dano em geral (Lei 10.406/02, que criou o Código Civil brasileiro), assim como os elementos que formam a responsabilidade civil ambiental (Lei n. 6.938/81, que cria a Política Nacional do Meio Ambiente e Lei n. 9.605/98, que tipifica os crimes ambientais e sanções administrativas por atividades lesivas ao meio ambiente) e a Lei n 7.347/85 (disciplina a ação civil pública e a responsabilidade por danos causados ao meio ambiente, ao consumidor, dentre outros).

Dentre os princípios estruturantes do Estado de Direito Ambiental, o dano ambiental está fundamentado nos princípios da precaução, da prevenção e da responsabilização, como analisado nos julgados anteriores. Cabe, ainda, analisar o princípio poluidor-pagador que motiva a indenização civil por dano ambiental, considerado a dimensão econômica da responsabilidade.

Referido princípio também é considerado estruturante do Estado de Direito Ambiental, pois reflete diretamente na imposição de responsabilidade àquele que assumiu o risco da atividade econômica desenvolvida e proporcionou, direta ou indiretamente, dano ambiental. Tal princípio, polluter-pays (poluidor-pagador), impõe ao poluidor o dever de arcar com os custos necessários ao combate à poluição, custos esses estabelecidos pelo Poder Público para manter a qualidade do meio ambiente em estado saudável. ${ }^{61}$

É importante destacar que não se trata de um princípio de compensação dos danos causados, no sentido de que, se poluiu, deve pagar, como se fosse uma fórmula matemática. Seria uma excelente arma para os empreendedores. 0 alcance deste princípio é bem maior, pois

\footnotetext{
${ }^{60} \mathrm{O}$ art. $4^{\circ}$, do Decreto-Lei 4657/42, que introduziu a Lei de Introdução ao Código Civil no ordenamento jurídico brasileiro, dispõe que "Quando a lei for omissa, o juiz decidirá o caso de acordo com a analogia, os costumes e os princípios gerais de direito".

${ }^{61}$ NEUFRAY, Jean-François. Droit de l'environnment. Bruxelles: Bruylant, 2001, p. 85.
} 
inclui os custos da prevenção, reparação e repressão do dano ambiental, vez que "o direito ambiental possui três esferas básicas de atuação: a preventiva, a reparatória e a repressiva". ${ }^{62}$

A ação preventiva deve ser a mais importante, já que a sanção é aplicada a posteriori, podendo a mesma ser inútil na proporção em que já foram concretizadas as conseqüências prejudiciais ao meio ambiente e à humanidade.

Observa-se que os danos sofridos pelo meio ambiente, na maioria dos casos, são irreparáveis, o que leva a perceber que a defesa do meio ambiente deve ser, sobretudo, preventiva que reparatória. Isto se deve ao fato de a reparação tratar da lesão concretizada, enquanto que a prevenção cuida da possibilidade de se impedir o dano.

Nesse esteio, o entendimento da Primeira Turma do ST) releva-se de forma amadurecer o instituto do dano ambiental no ordenamento jurídico brasileiro, em especial no que concerne a sua dimensão extrapatrimonial ao preencher as molduras deônticas acerca do tema, materializando, assim, as peculiaridades da responsabilidade civil ambiental.

5.5 REsp 904.324 / RS: a recuperação natural da área degradada não exime de responsabilidade o poluidor

O Ministério Público do Estado do Rio Grande do Sul ajuizou ação civil pública com a finalidade de responsabilizar Romeu Pedro Mior, ora recorrido, por danos causados ao meio ambiente, em virtude de derrubada de árvores e queimadas em área de $2.000 \mathrm{~m}^{2}$, situada no Município de Irai - RS.

Em suma, o parquet estadual faz os seguintes pedidos: a) a condenação do réu para apresentar projeto de reposição florestal, mediante acompanhamento e responsabilidade técnica de engenheiro agrônomo e florestal, contendo detalhes para orientar recuperação natural da área degradada, assim como acompanhamento e laudo técnico específico; b) seja o poluidor condenado, como medida compensatória aos danos causados, a efetuar doação de 1500 (hum mil e quinhentos) alevinos de dourado e/ou paia ou pagamento de valor correspondente.

Na sentença de primeiro grau, o juiz entendeu que o restabelecimento da área atingida pelo réu exime o empreendedor de responsabilidade, extinguindo, dessa forma, o processo sem resolução do mérito por perda de objeto. Resignado, o Ministério Público apresentou apelação que foi julgada improvida pelo Tribunal de Justiça pelos mesmos termos do juiz singular, motivo pelo qual foi interposto recurso especial para o STJ.

Ao analisar o caso, a relatora, Min. Eliana Calmon, observa que a instância ordinária não apreciou o mérito da demanda, não podendo o STJ fazê-lo, sob pena de supressão de instância. De todo modo, apesar da impossibilidade de acolher o pedido feito na exordial, a ministra destaca que as decisões anteriores não agiram de forma acertada, como se extrai do seu voto:

[...] como sobressai dos trechos da petição inicial anteriormente transcritos, a pretensão deduzida pelo parquet estadual ia além do mero plantio das oitocentas mudas de árvore, mas, sim, visava à apresentação de um projeto de reposição florestal, com acompanhamento e responsabilidade técnica de engenheiro agrônomo ou floresta. Assim, o simples fato de o recorrido ter se antecipado, procedendo o plantio das oitocentas árvores, desprovido de qualquer outro elemento de prova que demonstre a eficácia dessa medida em relação aos danos causados ao meio ambiente, em princípio, não afasta o interesse processual no julgamento da lide, cuja pretensão, como se viu, é mais ampla. ${ }^{63}$

$\overline{62}$ MILARÉ, Edis. Direito do ambiente: doutrina, prática, jurisprudência, glossário. 2. ed. São Paulo: Revista dos Tribunais, 2001. p. 419.

${ }^{63}$ SUPERIOR TRIBUNAL DE JUSTIÇA. REsp 904.324 / RS. Rel. Min. Eliana Calmon, Segunda Turma, julgado em 18.12.2008. DJ 27.05.2009, p. 6-7. 
Ao se tratar de dano ambiental, percebe-se que as medidas devem ser, de forma prioritária, na atuação da gestão preventiva. No entanto, diante da sua ocorrência, existem instrumentos de reparação e de repressão do mesmo, como manifestação dos princípios da solidariedade, da precaução, da prevenção, da responsabilidade e do poluidor-pagador, todos estruturantes do Estado de Direito Ambiental e abordados anteriormente.

Nesta senda, não basta a recuperação da área degradada, principalmente quando a mesma é realizada sem uma orientação técnica, como foi o caso em tela. Ademais, a regeneração in natura só atua no âmbito da reparação do dano ambiental, o que não exclui a dimensão repressiva, uma vez que referidas zonas de atuação do Direito Ambiental são independentes.

É o que ocorre no dano marginal devido ao tempo de desenvolvimento natural perdido em virtude da degradação. Ao levar para o instituto da responsabilidade civil tradicional, seria o lucro cessante, ou seja, o que a vítima deixou de ganhar em virtude do dano ocorrido. Aqui, segue a mesma lógica, pois se não tivesse ocorrida a degradação, as árvores teriam seguido seu desenvolvimento normal como proclama a teia natural da vida. Por isso é que o dano ambiental é, essencialmente, irreparável, haja vista que nunca será possível reparar o dano marginal.

Diante disso, a Segunda Turma do STJ concede parcial provimento ao recurso especial interposto pelo Ministério Público do Rio Grande do Sul para determinar o prosseguimento da ação, a fim de que o magistrado de primeira instância decida sobre o mérito da demanda de acordo com seu livre convencimento. De todo modo, é louvável o entendimento do STJ que aproveita o impulso jurisdicional e a relevância da temática para expor fundamentação teórica sobre o dano ambiental no ordenamento jurídico brasileiro.

\section{Conclusão}

Desconstruir teses, teorias e paradigmas no atual contexto da sociedade de risco é uma empreitada constante. São várias as antíteses levantadas, para utilizar a dialética dos opostos hegeliana, por conta das incertezas científicas. Por outro lado, defender atualmente algo sólido, uma síntese concreta, é um desafio que atinge todos os ramos do conhecimento científico.

Não se pode ler a Constituição de 1988 com a mesma lente do momento da sua promulgação. Por conta disso, por mais que o atual Texto Constitucional acentue que a República Federativa do Brasil constitui-se em um Estado Democrático de Direito, logo em seu art. 1으, não significa um engessamento do referido dispositivo. As condições fáticas e jurídicas, daquele momento, transformaram-se. É preciso reler a Constituição tendo como lente a crise ambiental e a sociedade de risco.

A construção do Estado de Direito Ambiental não se trata de um surgimento de um novo Estado. 0 que se busca é o fortalecimento de um novo olhar, de uma consciência ecológica, de diferentes funções, instrumentos, metas e tarefas que possam (e devam) ser utilizados pelo Poder Público e pela coletividade, de forma integrada, preventiva, precaucional e solidária.

A racionalidade jurídica clássica, pautada na segurança e em conceitos engessados, não é suficiente para lidar com a complexidade que permeia o dano ambiental. Ao transpor a teoria do risco para a responsabilidade civil, cujos elementos foram construídos sob as bases do racionalismo e das certezas científicas, é necessária a rediscussão do referido instituto, a fim de adequá-lo às exigências não apenas do risco concreto ou em potencial, mas principalmente do abstrato, que se revela como imprevisível pelo conhecimento humano. Em outras palavras, ao analisar o instituto do dano ambiental, não basta simplesmente importar os elementos da responsabilidade civil para o Direito Ambiental, sob pena de o sistema jurídico exercer uma função figurativa e simbólica, distante de uma efetiva proteção do meio ambiente

Parece que a própria materialização do que é segurança jurídica merece discussão de forma a compatibilizá-la com o princípio da precaução, quando se trata de risco em abstrato, 
incerto. Segurança jurídica não pode ser entendida como imutabilidade. Busca-se a segurança da relação jurídica, vínculo esse formado por membros da sociedade, leia-se, uma sociedade pós-moderna coberta pelo risco. Emerge, pois, uma dimensão da segurança jurídica ambiental com vistas a efetivar a justiça ambiental, pautada na solidariedade intergeracional.

Constata-se que a tutela preventiva do dano ambiental como medida prioritária em relação à reparação é um avanço na ordem jurídica brasileira. No entanto, as dificuldades se encontram na efetivação de referidos instrumentos que se tornam um grande desafio aos operadores do Direito Ambiental. A doutrina brasileira vem se mostrando sensível, aberta e comprometida com a complexidade do dano ambiental.

Entretanto, a previsão normativa e o embasamento doutrinário não são suficientes, pois a eficácia social da norma jurídica é condicionada, muitas vezes, aos aplicadores do Direito Ambiental. A jurisprudência exerce uma tarefa fundamental na solidificação e efetivação de todas em peculiaridades que circundam os riscos e danos ambientais.

Ao estudar os casos selecionados do STJ, conclui-se que a Corte Especial releva-se de forma a amadurecer o instituto do dano ambiental no ordenamento jurídico brasileiro, materializando, assim, de forma indutiva, as peculiaridades da responsabilidade civil por dano ecológico.

Como se vê, a complexidade dos riscos e danos ambientais, à luz da pós-modernidade e da sociedade de risco, parece romper - ou pelo menos abalar - as estruturas clássicas da própria epistemologia do Direito, revelando-se como um grande desafio não só para a efetivação do Direito Ambiental, mas para toda a ciência do Direito.

José Rubens Morato Leite

Professor Associado II dos Cursos de Graduação e Pós-Graduação de Direito da UFSC. Pós-Doutor pela Macquarie, Centre for Environmental Law, Sydney, Austrália. Doutor pela UFSC, com estágio de doutoramento na Faculdade de Direito da Universidade de Coimbra. Vice-Presidente do Instituto o Direito por Um Planeta Verde. Coordenador do Grupo de Pesquisa Direito Ambiental e Ecologia Política na Sociedade de Risco, cadastrado no CNPq/ GPDA/UFSC. Consultor e Bolsista do CNPq.

Germana Parente Neiva Belchior

Mestre em Direito Constitucional pela Universidade Federal do Ceará. Professora de Hermenêutica Jurídica e Aplicação do Direito, Direito Ambiental e Ecologia da Faculdade Christus - Fortaleza, onde também é colaboradora do Escritório de Direitos Humanos EDH. Pesquisadora do Projeto Casadinho (UFC/UFSC/CNPq). 


\section{Referências}

ARAGÃO, Maria Alexandra de Sousa. O princípio do poluidor-pagador: pedra angular da política comunitária do ambiente. Coimbra: Coimbra Editora, 1997.

. O princípio do nível elevado de protecção ecológica: resíduos, fluxos de materiais e justiça ecológica. Tese de Doutoramento. FDUC. Coimbra: 2004.

ARCHER, António Barreto. Direito do Ambiente e Responsabilidade Civil. Coimbra: Almedina, 2009.

AYALA, Patryck de Araújo. A proteção jurídica das futuras gerações na sociedade do risco global: direito ao futuro na ordem constitucional brasileira. IN: LEITE, Jose Rubens Morato e FERREIRA, Heline Sivini (ORG). Estado de Direito Ambiental: Aspectos Constitucionais e Diagnósticos. Rio de Janeiro: Forense Universitária, 2004.

BARROS, Wellington Pacheco. Curso de Direito Ambiental. 2. ed. São Paulo: Atlas, 2008.

BAUMAN, Zygmunt. O mal-estar da pós-modernidade. Tradução de Mauro Gama, Claudia Martinelli Gama. Rio de Janeiro: Jorge Zahar, 1998.

BECK, Ulrich. Ecological Politics in an Age of Risk. Londres: Polity Publications, 1995. . La sociedade del riesgo. Tradução de Jorge Navarro. Barcelona: Paidós, 1998.

BENJAMIN, Antonio Herman V. A Responsabilidade civil pelo Dano Ambiental no Direito Brasileiro e as Lições do Direito Comparado. Disponível em: 〈http://bdjur.stj.gov.br/dspace/bitstream/2011/8632/3/A_ Responsabilidade_Civil.pdf 〉. Acesso em: 20. ago. 2007.

. A Natureza no Direito Brasileiro: coisa, sujeito ou nada disso. In: Grandes Temas de Direito Administrativo: homenagem ao Professor Paulo Henrique Blasi. CARLIN, Volnei Ivo (org.). Campinas, Millenium, 2009.

. Constitucionalização do ambiente e ecologização da Constituição brasileira. In: LEITE, José Rubens Morato; CANOTILHO, José Joaquim Gomes (orgs.). Direito constitucional ambiental brasileiro. 2. ed. São Paulo: Saraiva, 2008.

BELCHIOR, Germana Parente Neiva. Hermenêutica e Meio Ambiente: uma proposta de Hermenêutica Ambiental para a efetivação do Estado de Direito Ambiental. 2009. 219 f. Dissertação (Mestrado em Direito Constitucional). - Universidade Federal do Ceará, Fortaleza, 2009.

CANOTILHO, José Joaquim Gomes. Protecção do ambiente e direito de propriedade: crítica de jurisprudência ambiental. Coimbra: Coimbra, 1995.

CAPELLA, Vicente Bellver. Ecologia: de las razones a los derechos. Granada: Ecorama, 1994.

CAVALIERI FILHO, Sergio. Programa de Responsabilidade civil. 8.ed. São Paulo: Atlas, 2008.

FENSTERSEIFER, Tiago. Direitos Fundamentais e Proteção do Ambiente. A Dimensão Ecológica da Dignidade Humana no Marco Jurídico-Constitucional do Estado Sociambiental de Direito. Porto Alegre. Livraria do Advogado, 2008.

FERRAZ, Sérgio. Responsabilidade civil por dano ecológico. Revista de Direito Público, São Paulo, V. 49, n.5O.

GIDDENS, Anthony. Mundo em descontrole: o que a globalização está fazendo de nós. 2. ed. Tradução de Maria Luiza X. de A. Borges. Rio de Janeiro: Record, 2002.

GONÇALVES, Carlos Roberto. Comentários ao Código Civil. São Paulo: Saraiva, 2003, v. 11.

HESSE, Konrad. A força normativa da Constituição. Tradução de Gilmar Ferreira Mendes. Porto Alegre: Sergio Antonio Fabris Editor, 2001.

KRELL, Andreas J. Discricionariedade Administrativa e proteção ambiental: o controle dos conceitos jurídicos indeterminados e a competência dos órgãos ambientais - um estudo comparativo. Porto Alegre: Livraria do Advogado, 2004.

LEITE, José Rubens Morato. Dano ambiental: do individual ao coletivo extrapatrimonial. 2. ed. São Paulo: Revista dos Tribunais, 2003.

LEITE, José Rubens Morato; FERREIRA, Maria Leonor Paes Cavalcanti Ferreira. As novas funções do Direito Administrativo em face do Estado de Direito Ambiental. In: Grandes Temas de Direito Administrativo: homenagem ao Professor Paulo Henrique Blasi. CARLIN, Volnei Ivo (org.). Campinas: Millenium, 2009.

LEITE, José Rubens Morato; BELCHIOR, Germana Parente Neiva. Estado de Direito Ambiental: uma análise da recente jurisprudência do STJ sob o enfoque da hermenêutica jurídica. Revista de Direito Ambiental, a. 14, v. 56, out./nov., p. 55-92, São Paulo: Revista dos Tribunais, 2009.

LEITE, José Rubens Morato; AYALA, Patrick de Araújo. Direito ambiental na sociedade de risco. Rio de Janeiro: Forense, 2004 . 
MILARÉ, Édis. Direito do ambiente: a gestão ambiental em foco. Doutrina, jurisprudência, glossário. 5. ed. São Paulo: Revista dos Tribunais, 2007.

. Amplitude, limites e prospectivas do Direito do Ambiente. In: Sustentabilidade e temas fundamentais de direito ambiental. MARQUES, José Roberto (org.). Campinas: Millennium, 2009. MORAES, Germana de Oliveira. Controle Jurisdicional da Administração Pública. 2. ed. São Paulo: Dialética, 2004.

NEUFRAY, Jean-François. Droit de l'environnment. Bruxelles: Bruylant, 2001.

PAUL, Wolf. A irresponsabilidade organizada? In: OLIVEIRA JUNIOR, José Alcebíades (org.). O novo em Direito e política. Porto Alegre: Livraria do Advogado, 1997.

ROCHA, Leonel Severo. Uma nova forma para a observação do direito globalizado: policontextualidade jurídica e Estado Ambiental. In: Grandes Temas de Direito Administrativo: homenagem ao Professor Paulo Henrique Blasi. CARLIN, Volvei Ivo (org.). Campinas: Millennium, 2009.

SENDIM, José de Sousa Cunhal. Responsabilidade civil por danos ecológicos: da reparação do dano através da restauração natural. Coimbra: Coimbra Editora, 1998 p. 167.

TEIXEIRA, Sálvio de Figueiredo. A criação e realização do Direito na decisão judicial. Rio de Janeiro: Forense, 2003. 